\title{
Articles
}

\section{Race and the Decision To Detain a Suspect}

\author{
Sheri Lynn Johnson†
}

Thirty years ago police stopped Malcolm X because he was a black man in a white neighborhood. ${ }^{1}$ A revolution in civil rights later, police still view race as an important factor in the decision to detain a suspect. The facts behind the recent Supreme Court case of Kolender v. Lawson ${ }^{2}$ are instructive: During a two-year period, Edward Lawson, a law-abiding black citizen with a penchant for strolling through white neighborhoods, was detained or arrested fifteen times under a California statute requiring "suspicious" persons to identify themselves to a policeman's satisfaction. Even more disturbing than this persistent discrimination is the limited and ambivalent response it has evoked from the courts. The judicial reaction to other disquieting indicia of suspicion, such as youth, a "hippie" appearance, or presence in a "crime-prone" neighborhood, has been similarly disorganized.

The Supreme Court has developed a two-tier standard for measuring the legality of a detention: The prosecution must establish "probable cause" to justify a full custodial arrest and it must show "reasonable suspicion" to justify an investigatory stop and frisk. ${ }^{3}$ Both concepts focus on

$\dagger$ Assistant Professor of Law, Cornell University. I wish to thank Professor Kevin M. Clermont for his detailed criticisms and comments on an earlier draft of this Article.

1. M. LitTle, The Autobiography of Malcolm X 145-46 (1964):

Our only close brush with the law came once when we were making our getaway, three of us in the front seat of the car, and the back seat loaded with stuff. Suddenly we saw a police car round the corner, coming toward us, and it went on past us. They were just cruising. But then in the rear-view mirror, we saw them make a U-turn, and we knew they were going to flash us to stop. They had spotted us, in passing, as Negroes, and they knew that Negroes had no business in the area at that hour.

2. 103 S. Ct. 1855 (1983) (voiding statute for vagueness).

3. See Terry v. Ohio, 392 U.S. 1, 20, 25-27 (1968). 
the aggregate information available to the police and stress the uniqueness of each constellation of facts. This focus has allowed the Court and commentators to neglect the question of whether some facts are impermissible constituents of that constellation.

Without systematic guidance concerning which facts may help to justify police interference with individual freedom, some lower courts give great deference to police testimony on criminal profiles and crime-prone neighborhoods, while others refuse to give any weight to these factors. It is therefore not enough to know that race alone will never establish probable cause or even reasonable suspicion; we must also ask whether or when race may be used to tip the scales from not-quite-probable cause to probable cause.

This Article addresses the permissible components of probable cause and reasonable suspicion. Part I shows how both probabilistic and constitutional considerations limit the factors that police may consider in deciding to detain suspects. Part II then examines the varied uses of race as an element in the determination of probable cause or reasonable suspicion. Part III criticizes these uses, questioning both whether race is relevant and whether the Fourteenth Amendment's equal protection clause in any case forbids its use. Finally, Part IV sketches possible applications of this method to other disputed indicia of criminal conduct.

\section{A FRAMEWORK FOR UNDERSTANDING CONSTRAINTS ON THE USE of Race in Detention Decisions}

The Fourth Amendment provides that a valid arrest warrant may issue only upon an oath or affidavit setting forth facts that establish probable cause. ${ }^{4}$ Because a lesser standard for warrantless arrests would have created a disincentive for procuring a warrant and would have provided a means of circumventing the Fourth Amendment, courts have readily inferred a probable cause requirement for warrantless arrests as well. $.^{5} \mathrm{De}-$ spite the courts' insistence on adherence to a probable cause standard, the concept itself remains sketchy. Probable cause is more than good faith suspicion; it requires a reasonable basis for belief in guilt. ${ }^{b}$ It "exists where 'the facts and circumstances within [the officers'] knowledge and of which they had reasonably trustworthy information [are] sufficient in themselves to warrant a man of reasonable caution in the belief that' an

4. U.S. Const. amend. IV. Because the Fourth Amendment's protections are "implicit in 'the concept of ordered liberty," the due process clause of the Fourteenth Amendment makes the Fourth Amendment applicable to the states. Wolf v. Colorado, 338 U.S. 25, 27-28 (1949).

5. See Wong Sun v. United States, 371 U.S. 471, 479-80 (1963).

6. See Carroll v. United States, 267 U.S. 132, 161-62 (1925). 
offense has been or is being committed." Because the totality of these facts and circumstances is central, "seldom does a decision in one case handily dispose of the next."

In Terry v. Ohio, ${ }^{\circ}$ the Supreme Court upheld a temporary investigative seizure and patdown-a "stop and frisk"-based upon less than probable cause. ${ }^{10}$ This less intrusive stop requires "reasonable suspicion," "articulable reasons," or "founded suspicion."11 Reasonable suspicion is present when an officer "observes unusual conduct which leads him reasonably to conclude in light of his experience that criminal activity may be afoot ...."12 Predictably, this concept also remains elusive. Because reasonable suspicion, like probable cause, focuses on the totality of the circumstances, "clear guidance dispositive of the myriad factual situations that arise" is impossible. ${ }^{13}$

Probable cause is more demanding than reasonable suspicion in two respects. The former reaches only completed or ongoing crimes, while the latter encompasses imminent criminal activity. Probable cause also demands greater confidence in the interpretation of the facts observed. For the purposes of this Article, however, these differences are irrelevant. Both standards require an estimation of the likelihood of an individual's wrongdoing and both justify action by state or federal law enforcement agents. These shared characteristics determine coextensive constraints-both probabilistic and constitutional-on the facts that may be relied upon to justify a suspect's detention.

\section{A. Probabilistic Constraints}

The Supreme Court has repeatedly commanded a unique calculation of the degree of suspicion generated by each particular fact pattern. Neither the courts nor legal scholars have sufficiently stressed the necessary first step of such a calculation: separating facts that contribute to the likelihood of criminal activity from those that do not.

7. Brinegar v. United States, 338 U.S. 160, 175-76 (1949) (quoting Carroll v. United States, 267 U.S. at 162).

8. Hinton v. United States, 424 F.2d 876, 879 (D.C. Cir. 1969) ("elements of a finding of probable cause are as varied as encounters between citizens and police"); see United States v. Davis, 458 F.2d 819, 821 (D.C. Cir. 1972) ("Viewed singly these factors [about defendant's behavior] may not be dispositive, yet when viewed in unison the puzzle may fit.").

9. 392 U.S. 1 (1968).

10. Id. at 26-27 (interests implicated in police intrusions short of decision to arrest do not require finding probable cause). If a suspect consents to being questioned, no seizure is involved and no justification is required. See Reid v. Georgia, 448 U.S. 438,440 n.* (1980).

11. See United States v. Cortez, 449 U.S. 411, 417-18 (1981) (discussing meaning of "articulable reasons" and "founded suspicion"); N.Y. CRIM. PROC. LAw \$140.50 (McKinney 1981) (requiring "reasonable suspicion" for stop and frisk).

12. Terry v. Ohio, 392 U.S. 1,30 (1968).

13. United States v. Cortez, 449 U.S. 411,417 (1981). 


\section{The Concepts of Probable Cause and Reasonable Suspicion}

"In dealing with probable cause, ... as the very name implies, we deal with probabilities."14 Similarly, the concept of reasonable suspicion "does not deal with hard certainties, but with probabilities."15 Mistakes are therefore possible, but they "must be those of reasonable men, acting on facts leading sensibly to their conclusions of probability." ${ }^{16}$ Thus, each fact contributing to probable cause must increase the probability that a crime has been, is being, or will be committed; it must be more often present when a particular crime (or type of crime) is being committed than when it is not. Because probable cause contemplates the totality of circumstances, a relevant fact is one that adds to the likelihood of criminal activity, given the other facts also observed. On the one hand, a bulge at the waistband may be significantly related to the carrying of contraband, but if it is observed in conjunction with other signs of obesity, it has no probative value. On the other hand, although riding a bicycle probably is not statistically related to the commission of any crime, riding one late at night in a warehouse district may correlate highly with participation in a burglary. Essentially, a reasonable police officer ignores those facts that, controlling for other observed facts, do not increase the likelihood of criminal activity.

Of course, focusing on probability does not require multiple regression analysis or other sophisticated statistical techniques. The Supreme Court has from the outset stated that the calculations involved "are not technical; they are the factual and practical considerations of everyday life on which reasonable and prudent men, not legal technicians, act."17 The Court has recently used similar language to explain that the probabilities relevant to reasonable suspicion are "commonsense" and must be applied "not in terms of library analysis by scholars, but as understood by those versed in the field of law enforcement." 18 Although the aim in selecting facts to justify probable cause or reasonable suspicion must be objective prediction, practicality tempers the precision of the prediction required.

14. Brinegar v. United States, 338 U.S. 160, 175 (1949).

15. United States v. Cortez, 449 U.S. at 418.

16. Brinegar v. United States, 338 U.S. at 176 (emphasis added).

17. Id. at 175 .

18. The Supreme Court has recently extended this commonsense standard to determinations which used to be somewhat more formalistic. See United States v. Cortez, 449 U.S. at 418; see also Illinois v. Gates, 103 S. Ct. 2317, 2228-32 (1983) (rejecting "rigid . . two-pronged test" for determining reliability of informants' tips established by Spinelli v. United States, 393 U.S. 410 (1969), and Aguilar v. Texas, 378 U.S. 108 (1964)). 


\section{Applications of the Concepts}

In most street detentions, a police officer's own observations or the observations of other officers prompt his action. ${ }^{19}$ The variety of "suspicious" facts or circumstances police may witness is nearly infinite, but most fall into one of four general categories. The simplest factor is conduct resembling a crime or necessary preparation for that crime. A more subtle factor that attracts police attention is conduct that appears to reflect consciousness of guilt. In addition, characteristics of the actor may either legitimate observed conduct or render it more suspect. Finally, the environment in which the actor is observed may aid in the interpretation of his conduct. The Supreme Court has never addressed the question of which of these categories of observations-or which subsets from each category-may properly contribute to probable cause or reasonable suspicion. Nevertheless, the Court's pronouncements on the nature of probable cause and reasonable suspicion, and the sporadic attempts by lower courts to exclude some observations as irrelevant, suggest a few general constraints.

Courts occasionally demand proof of a correlation between an allegedly suspicious fact and criminal activity, ${ }^{20}$ but most often they assume its relevance without discussion. No opinion of which I am aware explains when and why a demonstration of predictive power is necessary, but reference to the "commonsense" limit on the concept of probability suggests a distinction: When a fact is intuitively related to the commission of crime, defendants do not challenge its use and courts do not require extrinsic proof of correlation. For example, an officer might testify that he observed the defendant forcing open a door. Although dispute over the weight properly accorded to this fact is possible, dispute over its relevance is extremely unlikely. "Everyone knows" that this action increases the probability that a crime is in progress, and a police officer is entitled to rely upon collective knowledge of this kind. The conclusion that forcing a door is probative of criminal activity is derived from two empirical assumptions: (i) forcing a door frequently occurs as part of a burglary; and (ii) forcing a door rarely occurs in law-abiding behavior. Because neither of these assumptions really is debatable, courts can comfortably accept the resulting predictor without statistical proof.

Conduct Resembling a Crime.-Courts seldom demand proof that conduct resembling a crime or part of a criminal escapade is probative of criminal activity. When they do, it is often because knowledge of how the

19. Sep L. Tiffany, D. McIntrye \& D. Rotenberg, Detection of Crime 16-17 (1967).

20. See, e.g., United States v. Westerbann-Martinez, 435 F. Supp. 690, 698 (E.D.N.Y. 1977) (rejecting use of drug courier profile where no evidence was offered in support of its accuracy); United States v. Lopez, 328 F. Supp. 1077, 1101 (E.D.N.Y. 1971) (rejecting ethnic element of hijacker profile "for which there is no experimental basis"). 
criminal act is executed is not widespread. Some courts, for example, once required expert testimony that glassine envelopes were used to transport heroin before they would admit as evidence observations of a glassine envelope exchange. ${ }^{21}$ Extrinsic proof of criminal patterns is necessary when the first empirical assumption underlying a conclusion of relevance does not rely on common sense. ${ }^{22}$

Conduct that Appears to Reflect Consciousness of Guilt.-Conduct thought to reflect consciousness of guilt is more often challenged. In this kind of inquiry, the first empirical assumption relies on common sense: A criminal's awareness of his wrongdoing will prompt him to engage in secondary conduct designed to avoid detection or apprehension. The difficulty concerns the second assumption: Is the allegedly evasive conduct also so common among the innocent that it does not predict criminality?

Some indicators of evasion are clear. It is unlikely that an innocent person will flee a uniformed officer after a request to stop. ${ }^{23}$ When an officer insufficiently identifies his office or mission, however, courts may ascribe a citizen's "flight" to fear, distaste, or disinterest. ${ }^{24}$

Law enforcement agents cite an amazing variety of behavior as indicating consciousness of guilt. Police have inferred an attempt to conceal both from a traffic violator's reach toward the dashboard or floor of a car, and from his alighting from his car and walking toward the police. ${ }^{25}$ Drug Enforcement Agency officers have inferred a desire to avoid detection both from a traveler's being the last passenger to get off a plane ${ }^{26}$ and from his being the first. ${ }^{27}$ Immigration and Naturalization Service agents have ar-

21. Sep People v. Corrado, 22 N.Y.2d 308, 313, 239 N.E.2d 526, 529, 292 N.Y.S.2d 648, 651-52 (1968) (glassine envelopes "have come to be accepted as the telltale sign of heroin").

22. See People v. Alexander, 37 N.Y.2d 202, 203, 333 N.E.2d 157, 157, 371 N.Y.S.2d 876, 877 (1975) (empirical assumption supported by extrinsic evidence that more than half of officer's narcotics arrests involved glassine envelopes).

23. See Sibron v. New York, 392 U.S. 40, 66-67 (1968) (approving search of defendant because his "deliberately furtive actions and flight at sight of law officer were proper factors" in decision to arrest).

24. See Wong Sun v. United States, 371 U.S. 471, 482-83 (1963) (when plainclothes officer "affirmatively misrepresented" himself, defendant's flight offered "no ... inference of guilty knowledge"); People v. Howard, 50 N.Y.2d 583, 589-90, 408 N.E.2d 908, 912-13, 430 N.Y.S.2d 578,583 (defendant followed by unmarked police car driven by plainclothes officers might "have acted evasively out of fear for his own safety"), cert. denied, 449 U.S. 1023 (1980).

25. See People v. Superior Court, 3 Cal. 3d 807, 826-28, 478 P.2d 449, 462-63, 91 Cal. Rptr. $729,742-43$ (1970) (noting and rejecting claim of probable cause based on both "furtive gestures" and defendant's alighting from car).

26. See United States v. Mendenhall, 446 U.S. 544, 547 n.1 (1980) (leaving plane last an element in drug courier profile).

27. See J. Choper, Y. Kamisar \& L. Tribe, The Supreme Court: Trends and DevelopMENTS, 1979-1980, at 137-39 (1981). In discussing Mendenhall, Kamisar contrasts the DEA's reliance on Mendenhall's being the last person to exit from the plane with another prosecutor's reliance on a defendant's having been the first passenger off, and remarks that "[a]t this point, it would not surprise me if one of these days the government argues that a certain defendant met the profile because when the passengers deplaned he was exactly in the middle of the line-to avoid attracting attention, of course." Id. at 138. 
gued both that it was suspicious that the occupants of a vehicle reacted nervously when a patrol car passed, and that it was suspicious that the occupants failed to look at the patrol car. ${ }^{28}$ Finally, the government has argued in a customs case that "excessive" calmness is suspicious. ${ }^{29}$

Although police experience may fill in gaps in common knowledge concerning how frequently the observed conduct is part of a criminal activity, it cannot contradict a commonsense perception that the conduct is usually part of an innocent pattern. ${ }^{30}$ This may be because police are experts only on the antisocial, not the normal; perhaps if expert evidence of "normal" conduct were proffered, it would also be acceptable.

Characteristics of the Actor.-Police presumptions of criminal activity that are based on status or personal appearance operate in much the same way as do presumptions based on conduct resembling a crime. If a person is removing a tire from a car, knowledge that he is not the owner increases the probability that he is stealing the tire. If the driver of a car appears to be about twelve years old, his appearance predicts that he is driving without a license. These factors require no demonstration of relevance because "everyone knows" they supply or correlate strongly with an element of the offense in question: A person who commits larceny takes property he does not own, and a person who appears to be twelve is unlikely to be sixteen and therefore old enough to obtain a valid license.

The use of personal characteristics to infer propensity to commit a crime is more problematic. Police have on occasion asserted that youth, ${ }^{31}$ a "hippie" appearance, ${ }^{32}$ ethnicity, ${ }^{33}$ or race ${ }^{34}$ contribute to probable cause

28. See United States v. Escamilla, 560 F.2d 1229, 1233 (5th Cir. 1977) (rejecting claim of reasonable suspicion based on defendants' not looking at marked patrol car because INS had previously claimed that repeated glances at patrol car were grounds for suspicion).

29. See United States v. Himmelwright, 551 F.2d 991, 992-93 (5th Cir.), cert. denied, 434 U.S. 902 (1977).

Judges may doubt that these cited behaviors are unusual among those with clear consciences. When they are skeptical, however, they do not ask for either clinical or statistical evidence of frequency among the general population-they simply reject the factor as non-probative. See United States v. Andrews, 600 F.2d 563, 566 \& n.4 (6th Cir.) (according no weight to alleged nervousness and noting contradictory government arguments in prior cases), cert. denied sub. nom. Brooks v. United States, 444 U.S. 878 (1979); supra note 25.

30. See People v. Corrado, 22 N.Y.2d 308, 313 \& n.3, 239 N.E.2d 526, 529 \& n.3, 292 N.Y.S.2d 648, 651-52 \& n.3 (1968) (manila envelopes rejected as a telltale sign of drug traffic because commonly used for other purposes); People v. Brunson, 65 A.D.2d 684, 685, 409 N.Y.S.2d 733, 734

(1978) (brown paper bag rejected as hallmark of drug trade because of myriad non-criminal uses).

31. See Commonwealth v. Bacon, 411 N.E.2d 772, 775 (Mass. 1980) (rejecting claim that car occupants' youthfulness was probative); State v. Ruud, 90 N.M. 647, 648-49, 567 P.2d 496, 498 (Ct. App. 1977) (rejecting officer's "hunch" that "driver [who] just looked young to me" should be stopped).

32. See United States v. Sherman, 430 F.2d 1402, 1404, 1405-06 (9th Cir. 1970) ("hippie-type" appearance permissible element of probable cause calculus), cert. denied, 401 U.S. 908 (1971).

33. See United States v. Brignoni-Ponce, 422 U.S. 873, 877 (1975) (claiming correlation between apparent Mexican ancestry and illegal alien status); infra pp. 230-33, 239 (discussing illegal alien cases).

34. See United States v. McClain, 452 F. Supp. 195, 199 (E.D. Mich. 1977). 
or reasonable suspicion. Although these assertions are nonintuitive, courts usually accept them without requiring proof of statistical correlation.

Some of the confusion surrounding the use of personal characteristics as indices of criminality may stem from sub silentio judicial notice of wellknown criminological data. There are numerous studies showing statistically significant correlations between youth and crime, particularly street crime. ${ }^{35}$ These findings are both uncontradicted and well publicized. Formal introduction of these studies into evidence may be more "technical" than the concept of probable cause requires. Similarly, propensity arguments from the actor's status as an ex-convict may be so well supported by recidivism research that documentation is pointless. ${ }^{36}$ When, however, such data are not available, basing probable cause upon an actor's personal characteristics violates the probability constraint.

The Environment of the Actor.-Early Supreme Court decisions recognized that the environment in which certain conduct occurs can contribute to its suspiciousness. ${ }^{37}$ The first such decision approved consideration of the coincidence of a suspect's itinerary with the travel pattern of a smuggler; ${ }^{38}$ recent decisions approve consideration of a suspect's departure from a major narcotics "source city" and his arrival in a major narcotics distribution center ${ }^{30}$ This use of geography is conceptually sound if the itinerary is both common among criminals and relatively uncommon among innocent persons. If law enforcement agents cite too many (or too many commonplace) origin/destination patterns as congruent with criminal traffic, courts may-and should-reject their testimony. ${ }^{40}$

Building on the precedent surrounding travel patterns, police and prosecutors began to use congruence with local crime patterns in a second, more ambitious way. A police officer will testify that he observed the de-

35. In 1981 , approximately $67 \%$ of the persons arrested and charged with the serious crimes included in the FBI's Crime Index were younger than 25 and one third were younger than 18. U.S. Dep'T OF JUStice, FBI, UnIform Crime Reports for the United States 177 (1982) (Table 34).

36. For example, $80 \%$ of the adults in the FBI's Criminal History file who were arrested for robbery between 1970 and 1974 were repeat offenders, averaging five prior arrests each. C. SILBERman, Criminal Violence, Criminal Justice 49, 51 (1978).

37. In re the Apollon, 22 U.S. (9 Wheat.) 362,374 (1824) (that vessel was seized in remote area known to be haven for smugglers is relevant to, but not dispositive of, question of probable cause); Carroll v. United States, 267 U.S. 132, 159-60 (1925) (relevant to probable cause determination that defendants were driving in area known to be "one of the worst active centers for [bootlegging]"); Brinegar v. United States, 338 U.S. 160, 166-67 (1949) (same). Either direct proof or judicial notice of environmental factors is sufficient. Brinegar, 338 U.S. at 168.

38. In re the Apollon, 22 U.S. (9 Wheat.) 362, 374 (1824).

39. See United States v. Mendenhall, 446 U.S. 544, 547 n.1 (1980).

40. See United States v. Andrews, 600 F.2d 563, 566-67 (6th Cir.) (rejecting such testimony because "our experience with DEA agent testimony in other cases makes us wonder whether there exists any city in the country which a DEA agent will not characterize as either a major narcotics distribution center or a city through which drug couriers pass on their way to a major narcotics distribution center"), cert. denied sub nom. Brooks v. United States, 444 U.S. 878 (1979). 


\section{fendant at the corner of Sixth Street and Eighth Avenue and that the} junction of those two streets is located in a high crime area; the prosecutor will argue that the location itself increased the suspiciousness of the defendant's action. Although courts consistently deem crime rates relevant, ${ }^{41}$ commentators have expressed concern over the adverse effect on honest citizens living in high crime areas. ${ }^{42}$

41. See, e.g., United States v. Magda, 547 F.2d 756, 758 (2d Cir. 1976), cert. denied, 434 U.S. 878 (1977); United States v. Davis, 458 F.2d 819, 822 (D.C. Cir. 1972); People v. Rios, 51 Cal. App. 3d 1008, 1010, 124 Cal. Rptr. 737, 737-38 (1975); People v. Oden, 36 N.Y.2d 382, 385, 329 N.E.2d 188, 191, 368 N.Y.S.2d 508, 512 (1975); State v. Freeman, 64 Ohio St. 2d 291, 295, 414 N.E.2d 1044, 1047 (1980), cert. denied, 454 U.S. 822 (1981).

42. See J. Skolnick, Justice Without Trial 218 (2d ed. 1975):

If an honest citizen resides in a neighborhood heavily populated by criminals, just as the chances are high that he might be one, so too are the chances high that he might be mistaken for one. The probabilities, from the point of view of the individual, are always the same-either he is or is not culpable. Thus, behavior which seems "reasonable" to the police because of the character of the neighborhood is seen by the honest citizen in it as irresponsible and unreasonable. About him, more errors will necessarily be made under a "reasonableness" standard.

Judicial caution has been limited to expression of concern that police attribute too much weight to a high crime neighborhood setting, sometimes detaining a suspect for mere residence in a ghetto. See United States v. Thomas, 551 F.2d 347, 348 (D.C. Cir. 1976); People v. Bower, 24 Cal. 3d 638, 645, 156 Cal. Rptr. 856, 860, 597 P.2d 115, 119 (1979); People v. McRay, 51 N.Y.2d 594, 606-07, 416 N.E.2d 1015, 1021-22, 435 N.Y.S.2d 679, 685-86 (1980) (Fuchsberg, J., concurring).

The courts should be more cautious. The basis for declaring an area crime-prone may be flimsy. Some police officers describe all areas as "crime-prone." See Racine v. State, 51 Ala. App. 484, 488, 286 So. 2d 890, 894 (Crim. App. 1973) (approving characterization of "upper class" neighborhood as burglary-prone). Even when an officer describes an area as crime-prone and relates the number of arrests he has made in it, courts should require evidence that such a number is unusually high.

In addition, unless there is some identity between the prevalent crime and the crime suspected, a "crime-prone" neighborhood does not increase the probability that a particular crime is being committed. See People v. Lathan, 38 Cal. App. 3d 911, 915, 113 Cal. Rptr. 648, 651 (1974) (noting that officer's testimony about crime in area never revealed kind of criminal activity to which he was referring). In a state where consensual sodomy is illegal, for example, a gay community may be demonstrably "crime-prone," but this is irrelevant if the crime suspected is a drug deal. Conversely, in a community that has a low overall crime rate but a disproportionate number of rapes, police may consider that pattern when investigating possible rape. See State v. Irwin, 191 Neb. 169, 181, 214 N.W.2d 595, 603 (1974).

Finally, even the information that a neighborhood has many drug transactions does not insure that a street exchange occurring in that neighborhood is more likely to be a drug deal than is an exchange in an ordinary neighborhood. In order to increase the probability of a parlicular exchange's being drug-related, a higher proportion of street transactions in the drug-prone area (not merely a higher number) must involve controlled substances. An equation between number and proportion requires the additional empirical assumption that the drug-prone neighborhood has the same number of street exchanges as does the control neighborhood. Since most poor neighborhoods have substantially more street activity than do suburban neighborhoods-both innocent and culpable-this assumption is improbable. A weaker assumption is possible: The high drug traffic area has proportionately less additional street activity than additional drug sales. This assumption, if correct, would also give the factor of neighborhood predictive power, but the lesser weight should be acknowledged. The leap from higher numbers to higher proportion is only troublesome in possessory crimes; it is quite likely that the legal transport of valuable objects at night is as unusual in a burglary-prone area as in a peaceful one. See Commonwealth v. Holloway, 229 Pa. Super. 128, 130-31, 323 A.2d 216, 217 (1974); State v. Sinclair, 11 Wash. App. 523, 523 P.2d 1209 (1974). 


\section{B. Other Constitutional Constraints}

Despite the lack of clear and consistent standards, courts attempt to apply Fourth Amendment requirements to all detention decisions. In contrast, they rarely consider the application of other constitutional constraints. Perhaps this is because a focus on Fourth Amendment constraints can increase the accuracy of detention decisions, while consideraton of nonprobabilistic constitutional constraints can only decrease accuracy. Nonetheless, the Fourth Amendment is not a constitution unto itself. Law enforcement cannot be exempted from compliance with other constitutional provisions. The values behind those other provisions must trump efficient police work. Some of these constitutional provisions, like probable cause, circumscribe the facts that may properly be considered in a decision to detain.

\section{Historical Fair Trial Considerations}

That facts would be inadmissible as evidence at trial no longer precludes their use in establishing probable cause or reasonable suspicion. Although early Supreme Court dicta stated that "[a] search warrant may issue only upon evidence which would be competent in the trial of the offense before a jury," ${ }^{34}$ the Court later rejected this position in Brinegar v. United States: ${ }^{44}$

[The emphasis on the criterion of admissibility into evidence at trial] goes much too far in confusing and disregarding the difference between what is required to prove guilt in a criminal case and what is required to show probable cause for arrest or search. . . . There is a large difference between the two things to be proved, as well as between the tribunals which determine them, and therefore a like difference in the quanta and modes of proof required to establish them. ${ }^{45}$

The information at issue in Brinegar-the defendants' pending indictment on a similar charge-was inadmissible at trial not for its lack of probative value, but for its potentially prejudicial effect upon the jury. Because the issue of probable cause is tried by a judge, the Court deemed concern over prejudice at a suppression hearing unnecessary. ${ }^{46}$ Thus, the rule that ra-

43. Grau v. United States, 287 U.S. 124, 128 (1932); see Worthington v. United States, 166 F.2d 557, 564-65 (6th Cir. 1948) (applying Grau to search warrants).

44. 338 U.S. $160(1949)$.

45. Id. at 172-73.

46. Id. at 173. Prior arrests and convictions, although not admissible at trial to prove guilt, are considered on the issue of probable cause for the same reasons. See, e.g., United States v. McNally, 473 F.2d 934, 940 (3d Cir. 1973) (prior convictions and arrests relevant to determination of suspi- 
cial propensity arguments are not permitted at trial does not in itself preclude such arguments at suppression hearings.

\section{Fourteenth Amendment Constraints}

Although fair trial evidentiary safeguards do not now limit the facts to be considered in a decision to detain, some other constitutional protections clearly do. ${ }^{47}$ The Fourteenth Amendment has thus far been largely unexplored in this context, yet it has the potential to restrict significantly the probative information police may use to justify detentions. In its command that no state "deny to any person within its jurisdiction the equal protection of the laws," 8 the Fourteenth Amendment requires that "all persons similarly circumstanced shall be treated alike."49 Thus, an official's decision to detain a suspect violates the Constitution if it "make[s] unjust and illegal discriminations between persons in similar circumstances."

In assessing an equal protection claim, a court "must first determine what burden of justification the classification created thereby must meet by looking to the nature of the classification and the individual interests

ciousness); United States v. Manning, 448 F.2d 992, 999-1000 (2d Cir.) (en banc) (prior conviction properly considered), cert. denied, 404 U.S. 995 (1971); Commonwealth v. Gullett, 459 Pa. 431, 437-38, 441, 329 A.2d 513, 516, 518 (1974) (prior arrests properly considered).

47. The Fourth Amendment requires that when illegally acquired evidence is exploited to obtain other evidence, the derivative evidence is inadmissible as "fruit of a poisonous tree." Wong Sun v. United States, 371 U.S. 471, 484-85 (1963). Thus, if a search which violates the defendant's legitimate expectations of privacy uncovers real evidence, that evidence may not be used to establish probable cause of his arrest. But see Commonwealth v. Weiss, 348 N.E.2d 787, 790 (Mass. 1976) (where information independent of illegal search provides sufficient factual basis for probable cause, illegal search will not taint arrest or require suppression of its fruits). The seizure clause mandates a similar exclusion of some relevant facts: If an illegal stop and frisk prompts incriminating statements from the defendant, those statements cannot be used to justify his subsequent arrest. Violations of statutory wiretapping restrictions are similarly subject to the poisonous fruits doctrine. See Nardone v. United States, 308 U.S. 338, 339-41 (1939).

Because the poisonous fruits doctrine has also been applied to unconstitutionally conducted lineups, see United States v. Wade, 388 U.S. 218, 239-42 (1967), and illegally obtained confessions, see Harrison v. United States, 392 U.S. 219, 222-26 (1968), the due process clauses of the Fifth and Fourteenth Amendments and the privilege against compulsory self-incrimination further circumscribe the facts that the prosecution may use to establish probable cause. Theoretically, facts justifying detention decisions are thereby limited. The rules of standing, however, make it difficult for a defendant to challenge detention decision criteria. While a statement from a third party or a lineup involving a codefendant may help establish the predicate for the defendant's arrest, the defendant does not have standing to challenge the legality of those events. Lineups or statements violating the defendant's own Fifth Amendment rights usually do not form the basis of his detention, but follow from it. Thus, the Fourth Amendment itself provides the only frequently observed nonprobabilistic constraint on detention decisions.

48. U.S. ConST. amend. XIV, \& 1.

49. F.S. Royster Guano Co. v. Virginia, 253 U.S. 412, 415 (1920) (striking down state tax law favoring local corporations). The due process clause of the Fifth Amendment contains an equal protection component similarly constraining the United States. See Bolling v. Sharpe, 347 U.S. 497, 499 (1954) (striking down school segregation in District of Columbia). Together, they subject to judicial scrutiny all governmental actions that classify individuals for different benefits or burdens.

50. Yick Wo v. Hopkins, 118 U.S. 356, 374 (1886) (invalidating facially neutral laundry ordinance enforced discriminatorily against Chinese). 
affected." "51 Because the individual interest affected by decisions to detain-freedom from police interference-has never been deemed a "fundamental interest" for purposes of equal protection analysis, most criteria for detention need only "bear[ ] some fair relationship to a legitimate public purpose." ${ }^{\prime 2}$ This minimal scrutiny dovetails with the definitional requirements of probable cause and reasonable suspicion since it allows consideration of any statistically relevant information.

Classifications that disadvantage a suspect class, such as a racial minority, must be "precisely tailored to serve a compelling governmental interest." "Wh When these classifications are used to determine whom the police may detain, this greater burden of justification should be placed on the government. Nevertheless, courts reviewing detention decisions eschew the heightened scrutiny analysis accorded these classifications in other contexts. ${ }^{\text {s4 }}$ I turn now to detention decisions relying upon the most notorious of these classifications: race.

\section{Present Uses of Race in Detention Decisions}

Police sometimes assert that a suspect's race contributed to their decision to detain him. Although no case condones race as the sole basis for an investigative stop, ${ }^{55}$ courts often allow it to tip the scales of probable cause or reasonable suspicion. Most approving opinions address neither the probabilistic nor the constitutional obstacles discussed in Part I.

\section{A. Identification of a Particular Offender}

Law enforcement officers routinely use race as a detention factor when a victim or witness has described the perpetrator of a particular crime; such descriptions almost always include the perpetrator's race. Courts reject objections that race should be ignored in this situation. ${ }^{56}$ As one opin-

51. Memorial Hosp. v. Maricopa County, 415 U.S. 250, 253 (1974) (invalidating residency requirement for provision of free non-emergency medical care to indigents); see Zablocki v. Redhail, 434 U.S. 374,383 (1978) (striking down Wisconsin statute requiring residents to prove payment of child support before remarriage).

52. Plyler v. Doe, 457 U.S. 202, 216 (1982) (describing standard to be used in reviewing most forms of state action).

53. Id. at 217. In addition, forms of classification such as gender-based distinctions which, while not suspect, "give rise to recurring constitutional difficulties," $i d$., must "serve important governmental objectives and must be substantially related to the achievement of those objectives." Craig v. Boren, 429 U.S. 190, 197 (1976) (establishing level of scrutiny for gender-based distinctions).

54. The Supreme Court has applied strict scrutiny to racial classifications in other areas of criminal procedure. See Strauder v. West Virginia, 100 U.S. 303, 308-10 (1880) (invalidating state statute restricting jury service to white males); Ex parte Virginia, 100 U.S. 339 (1880) (upholding prosecution of judge who excluded blacks from grand juries).

55. See United States v. Brignoni-Ponce, 422 U.S. 873, 885-87 (1975) (ethnicity alone cannot supply reasonable suspicion).

56. See United States v. Collins, 532 F.2d 79, 82 (8th Cir.), cert. denied, 429 U.S. 836 (1976); 
ion explains, race per se does not form the basis for a stop, but "is simply a characteristic which may properly be used as one element of identification." No disparate treatment is involved: "If, in this case, the race of those both described and apprehended were caucasian or oriental, rather than black-and all other circumstances were identical-there is no doubt but that the same result would follow."'s8

Occasionally, however, the coincidence of the suspect's and the perpetrator's race seems to be the only factor supporting the detention. In United States v. Collins, ${ }^{6 \theta}$ for example, the Eighth Circuit upheld the stop of a black man alone in a white Gadillac based on the information that a bank several miles away had been robbed by three black men in a brown Gadillac. $^{\circ 0}$ The majority explained simply that "the color of a person's skin . . . is an identifying factor which . . . assists the police in narrowing the scope of their identification procedure." ${ }^{31}$ In dissent, Judge Heany argued that a racial description can never create suspicion of a particular person, but can only eliminate from suspicion all persons of another race. ${ }^{62}$ Although Heany's position is unique, some courts have refused to give much weight to congruence between the perpetrator's and the suspect's race, ${ }^{6 s}$ and others have deemed congruence sufficient only when few persons of the perpetrator's race are present in the area. ${ }^{.4}$

\section{B. Incongruity}

Police manuals often instruct officers to become familiar with their beat and question persons who do not "belong."

Franklin v. State, 374 So. 2d 1151, 1153-54 (Fla. Dist. Ct. App. 1979), cert. denied, 388 So. 2d 1113 (Fla. 1980); Patterson v. State, 270 Ind. 469, 473, 386 N.E.2d 936, 939 (1979), cert. denied, 444 U.S. 935 (1980); State v. Buic, 297 N.C. 159, 162, 254 S.E.2d 26, 28 (1979), cert. denied, 444 U.S. 971 (1980).

57. Franklin v. State, 374 So. $2 \mathrm{~d}$ at 1154.

58. Id.

59. 532 F.2d 79 (8th Cir.), cert. denied, 429 U.S. 836 (1976).

60. Id. at 81, 83; see also Commonwealth v. Hicks, 209 Pa. Super. 1, 4, 223 A.2d 873, 875 (1966) (report of black burglar with mustache in brown coat justifies stop of black without mustache but in need of shave in light colored coat).

61. 532 F.2d at 82 .

62. Id. at 85-86 (Heany, J., dissenting).

63. See Commonwealth v. Sams, 465 Pa. 323, 326-28, 350 A.2d 788, 789-90 (1976) (stopping black youths in area where violent black gang fight occurred insufficiently founded on racial coincidence); Commonwealth v. Berrios, 437 Pa. 338, 341-42, 263 A.2d 342, 344 (1970) (probable cause not established when only reasons for stopping defendant were his race and proximity to scene of crime).

64. See Smith v. Swenson, 328 F. Supp. 747, 752 (W.D. Mo. 1971); People v. Grice, 87 IIl. App. 3d 718, 723, 410 N.E.2d 209, 214-15 (1980), cert. denied, 450 U.S. 1003 (1981); State v. Anderson, 204 Neb. 186, 188, 193, 281 N.W.2d 743, 745, 747 (1979); see also infra pp. 229-30, 243, 246-49 (discussing use of racial incongruity in detention decisions).

65. See J. Klotter \& J. Kanovitz, Constitutional. Law for Police § 2.6 (3d ed. 1977) (citing several police manuals" instructions concerning "suspicious persons"); L. TIFfanY, D. McINTYRE \& D. ROTENBERG, supra note 19 , at 38-39 (same). 
studies report that this practice is an important part of police patrol behavior. ${ }^{6 B}$ When the incongruity prompting police action is the suspect's race, the few courts that have considered the issue are divided in their responses.

In Arizona, for example, it is now well settled that racial incongruity may contribute to suspicion. In State $v$. Ruiz ${ }^{67}$ police officers walking on their beat observed the defendant, a Hispanic, enter a liquor store. The officers explained "that it was very unusual to see a person of either 'white' or Mexican descent in this particular area, and that it had been their experience in the past that the few 'whites' or Mexicans who were in the area were there for the purpose of purchasing narcotics." court held that this information alone gave rise to reasonable suspicion. ${ }^{6 \theta}$

In State v. Dean ${ }^{70}$ the Supreme Court of Arizona approved Ruiz. Police officers observed Mr. Dean sitting in a dented car parked in front of a small apartment complex. He appeared to be nervous and the arresting officer testified, "you know, when we first observed him we could tell that something wasn't correct. He just didn't look, I mean-he was a Mexican male in a predominantly white neighborhood of-oh, middle to uppermiddle class people . . ." Th1 The court found that these facts established reasonable suspicion, then addressed Dean's objection to reliance on his ethnicity:

The transcript indicates that Dean's ethnic background was only one of several factors which caused the officers to believe that further investigation was necessary. That a person is observed in a neighborhood not frequented by persons of his ethnic background is quite often a basis for an officer's initial suspicion. To attempt by judicial fiat to say he may not do this ignores the practical aspects of good law enforcement. While detention and investigation based on ethnic background alone would be arbitrary and capricious and therefore impermissible, the fact that a person is obviously out of place in a particular neighborhood is one of several factors that may be considered by an officer and the court in determining whether an investigation and detention is reasonable and therefore lawful. ${ }^{72}$

Arizona courts are extreme in requiring very little besides racial incongruity to justify a Terry stop. Several courts have implied that unexpected

66. For classic studies in this area, see W. LAFave, ArRest: The Decision to Take a SusPect into Custody (1965); L. Tiffany, D. MCInTYRe \& D. Rotenberg, supra note 19, at $18-43$.

67. 19 Ariz. App. 84, 504 P.2d 1307 (1973).

68. Id. at 84, 504 P.2d at 1307.

69. Id. at 86, 504 P.2d at 1309 .

70. 112 Ariz. 437, 543 P.2d 425 (1975).

71. Id. at 439,543 P.2d at 427 .

72. Id. (emphasis added). 
racial presence may contribute to reasonable suspicion, but hold that it is far from sufficient. In United States $v$. Richard, ${ }^{\text {23 }}$ for example, the Third Circuit noted that "the presence of two black males cruising in a car in a predominantly white neighborhood is, by itself, insufficient cause for a belief that those persons have participated in a recent crime in the neighborhood." "Similarly, in Commonwealth v. Bodden, ${ }^{78}$ the Massachusetts Appeals Court reversed a trial judge's finding that the defendant's race and rate of movement alone constituted reasonable suspicion. ${ }^{76}$

California has decided the matter differently. In People v. Bower, ${ }^{77}$ the arresting officer testified that his decision to arrest the appellant, a white male, was based upon the appellant's presence at night in a black area "where the officer had never observed a white person 'on foot in the hours of darkness . . . for innocent purpose." Th8 The court rejected an inference of suspicion on both Fourth Amendment and state constitutional grounds:

Initially, the fact that appellant was a white man could raise no reasonable suspicion of crime. A person's racial status is not an "unusual" circumstance and the presence of an individual of one race in an area inhabited primarily by members of another race is not a sufficient basis to suggest that crime is afoot. Freedom to travel and associate are fundamental rights in this state, and the suggestion that their exercise can contribute to a lawful seizure of one's person under these circumstances is both illogical and intolerable. ${ }^{78}$

The state's contention that the officer's experience with white outsiders was "specialized knowledge" entitled to judicial deference did not impress the majority. The court recalled earlier decisions noting that the use of data about the alleged crime rate of an area is easily subject to abuse, then analogized that 'it should be obvious that one officer's perception of the criminal tendencies of a racial group is far more so."80

The strangest race-as-incongruous-and-therefore-suspicious case is United States $v$. Magda. ${ }^{81}$ According to the district court, the arresting

73. 535 F.2d 246 (3d Cir. 1976).

74. Id. at 248 (emphasis added) (but also holding that incongruity may properly be a factor).

75. 1981 Mass. App. Ct. Adv. Sh. 560, 417 N.E.2d 468 (1981).

76. Id. at 560-61, 417 N.E.2d at 468-69; see also People v. Estrialgo, 37 Misc. 2d 264, 265, 276, 284, 233 N.Y.S.2d 558, 561, 571, 579 (Sup. Ct. 1962) (Puerto Rican youngsters' carrying expensive luggage in white neighborhood of Brooklyn Heights does not establish probable cause), rev'd on other grounds, 19 A.D.2d 509, 245 N.Y.S.2d 850 (1963), aff'd, 14 N.Y.2d 783, 189 N.E.2d 384, 250 N.Y.S.2d 293 (1964).

77. 24 Cal. 3d 638, 597 P.2d 115, 156 Cal. Rptr. 856 (1979).

78. Id. at 644,597 P.2d at 119,156 Cal. Rptr. at 860 .

79. Id. at $644-45,597$ P.2d at $119,156 \mathrm{Cal}$. Rptr. at 860 .

80. Id. at 646-47, 597 P.2d at 120, 156 Cal. Rptr. at 861 (emphasis in original). Justice Clark in dissent condemned the majority's disregard of the officer's expertise as a "cruel hoax" that would sentence the neighborhood's law-abiding residents to "further inhumanity." Id. at $650 \overline{\text {, }} 597$ P.2d at 123, 156 Cal. Rptr. at 864 (Clark, J., dissenting).

81. 409 F. Supp. 734 (S.D.N.Y.), rev'd, 547 F.2d 756 (2d Cir. 1976). 
officer's sole justification for stopping the white defendant was the officer's observation of an exchange between the defendant and a young black man in a "narcotics-prone" area. The officer did not describe the exchange as furtive; neither participant fled; and after the exchange the defendant turned toward the officer and walked past him. The court suppressed the evidence, noting that

There [was] nothing in the record to show that it is more likely than not that narcotics dealing can be reasonably expected to generate this kind of encounter between a young white and a young black person than between two men of the same race, between two women, or between any two human beings of any different ethnic origin or class. $^{82}$

The Second Circuit reversed. ${ }^{83}$ Citing the District of Columbia Circuit's admonition that "the circumstances before [the officer] are not to be dissected and viewed singly; rather they must be considered as a whole," the appeals court held that the officer's conduct was reasonable given the combination of circumstances present. ${ }^{85}$ Despite this stress on considering all the facts, the opinion nowhere mentioned that the exchange was an interracial one, but relied vaguely on the officer's "expertise." Judge Motley's dissent attacked the characterization of the area as crime-prone, revealed the sharply limited nature of the officer's expertise, and pointed out the ordinary and innocuous nature of the exchange and parting, ${ }^{88}$ but she too ignored the interracial aspect focused on by the lower court.

In another racial incongruity case of the speak-no-evil genre, People $v$. Tinsley, ${ }^{87}$ a New York appeals court affirmed a conviction without stating the facts in the case, citing only the officer's "street-wise" observations and expertise. ${ }^{88}$ The dissent, however, protested that the defendant's actions were totally innocuous and that "the ethnic identity of these three boys is what really caused alarm because of the area in which they were walking." ${ }^{\text {Bg }}$ The New York Court of Appeals summarily reversed, stating only that it relied upon the dissenting opinion in the Appellate Division. ${ }^{80}$

82. 409 F. Supp. at 740.

83. 547 F.2d 756 (2d Cir. 1976).

84. Id. at 758 (quoting United States v. Hall, 525 F.2d 857, 859 (D.C. Cir. 1976)).

85. 547 F.2d. at 758-59.

86. Id. at 761-65 (Motley, J., dissenting).

87. 48 A.D.2d 779, 369 N.Y.S.2d 142 (1975), rev'd sub nom. People v. T., 39 N.Y.2d 1028, 355 N.E.2d 302, 387 N.Y.S.2d 247 (1976).

88. Id. at 779, 369 N.Y.S.2d at 143. The defendant and several other youths had been strolling up a street, briefly looking into store windows and entering several stores, before they walked into a residential area. Id. at 780, 369 N.Y.S.2d at 143-44 (Stevens, P.J., dissenting).

89. Id. at 781,369 N.Y.S.2d at 146.

90. People v. T., 39 N.Y.2d 1028, 1029, 355 N.E.2d 302, 302, 387 N.Y.S.2d 247, 248 (1976). 
Finally, the Supreme Court's decision last Term in Kolender v. Lawson, ${ }^{\text {91 }}$ which invalidated a California statute requiring suspicious citizens to identify themselves to police, never mentioned that the respondent, who had been arrested fifteen times, was a black male who wore his hair in dreadlocks, and had been arrested while walking in white neighborhoods.

\section{G. Illegal Aliens}

The Immigration and Naturalization Service (INS) employs race as an element in establishing probable cause in searches for illegal aliens. Sometimes, the INS uses race simply as an identifying factor ${ }^{92}$ In the vast majority of litigated cases, however, the INS has no description of a particular alien, yet claims that the defendant's Hispanic or Asian appearance contributed to the decision to detain him. ${ }^{93}$

The Supreme Court has twice approved the use of race as a legitimate factor in INS detention decisions. In United States v. Brignoni-Ponce, ${ }^{94}$ the Court considered whether roving border patrols could detain persons absent reasonable suspicion. A substantial portion of the defendant's brief was devoted to arguing that the stops at issue were based upon race and that, regardless of their legitimacy under the Fourth Amendment, they violated the equal protection component of the Fifth Amendment's due process clause. $^{95}$ The argument relied upon traditional equal protection cases such as Yick Wo v. Hopkins, ${ }^{96}$ Korematsu v. United States, ${ }^{97}$ and Loving $v$. Virginia. ${ }^{98}$ The United States first claimed that the stops were based upon more than race, ${ }^{99}$ and then argued that consideration of racial appearance was permissible:

91. 103 S. Ct. 1855 (1983).

92. See United States v. Rodriguez, 532 F.2d 834, 836-38 (2d Cir. 1976) (agent justified in questioning person of Hispanic appearance outside house suspected of harboring illegal aliens); United States v. Chaidez-Castro, 430 F.2d 766, 769 (7th Cir. 1970) (police may use racial appearance in combination with other factors in deciding to search truck for illegal aliens).

93. See Cheung Tin Wong v. United States, 468 F.2d 1123, 1127-28 (D.C. Cir. 1972) (INS investigator acted on reasonable suspicion in detaining person of Asian appearance given surrounding circumstances); Hon Keung Kung v. District Director, INS, 356 F. Supp. 571, 575 (E.D. Mo. 1973) (race relevant factor in deciding to question person of Oriental appearance in room indicated by an informant).

94. 422 U.S. 873 (1975).

95. Brief for Respondent at 46-55, United States v. Brignoni-Ponce, 422 U.S. 873 (1975).

96. 118 U.S. 356 (1886) (municipality may not arbitrarily and unjustly discriminate on basis of race in administration of municipal ordinance).

97. 323 U.S. 214 (1944) (holding constitutional executive order excluding persons of Japanese descent from West Coast military area during war emergency).

98. 388 U.S. 1 (1967) (holding unconstitutional state statute intended to prevent marriages between persons solely on basis of racial classifications).

99. Reply Brief for the United States at 2-3, United States v. Brignoni-Ponce, 422 U.S. 873 (1975). 
The officers' actions were not invidiously discriminatory. It is because racial or ethnic characteristics are in most circumstances irrelevant that discrimination on the basis of such characteristics is forbidden. . . . Since the class of violators is composed of persons who are likely to appear to be of Mexican descent, it is not impermissible for law enforcement officers to take that fact into account in determining which persons should be asked about their citizenship. The situation here is analogous to that in which law enforcement officers are given descriptions of robbery suspects that include the suspects' race. Surely it would not be impermissible for the officers to limit their investigation to persons who fit the descriptions. Similarly, "common sense [dictates] that. race may be a relevant factor in some circumstances in determining whether to question a person about his immigration status." 100

The Court's opinion sidestepped these equal protection arguments, holding that roving border patrols could not detain persons absent reasonable suspicion, ${ }^{101}$ and that even in border areas, apparent Mexican descent alone did not supply that suspicion. ${ }^{102}$ Then, in careful and clipped dicta, the Court approved a more restrained use of race: "The likelihood that any given person of Mexican ancestry is an alien is high enough to make Mexican appearance a relevant factor....."103

The Court again confronted the use of race by the INS in United States v. Martinez-Fuerte. ${ }^{104}$ The majority approved both routine stops at a permanent checkpoint located away from the border and selective referrals for further questioning not supported by reasonable suspicion. The majority perceived "no constitutional violation" even if referrals for secondary interrogation were based largely upon apparent Mexican ancestry; the opinion rationalized unequal treatment by citing the minimal nature of the intrusion involved and the need for broad discretion. ${ }^{105}$ Despite the defendant's invocation of the equal protection clause, ${ }^{108}$ the Court again declined to employ it. In a footnote, the Court cited statistics showing that twenty percent of the vehicles referred to the secondary inspection area contained illegal aliens as proof that the existing reliance on race "clearly is relevant to the law enforcement need to be served."107 The majority expressed a single tentative caveat: "[D]ifferent considerations" would ap-

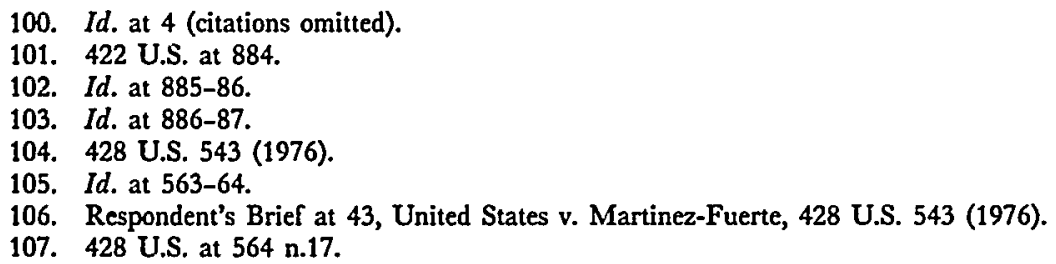


ply if agents near the Ganadian border relied upon Mexican ancestry to decide when to conduct secondary inspections. ${ }^{108}$

Justice Brennan, joined in dissent by Justice Marshall, objected both to the abandonment of the reasonable suspicion requirement and to the discrimination that its abandonment would permit against citizens of Mexican ancestry. ${ }^{109}$ The dissent saw the selective nature of the referrals as more, rather than less, intrusive because their ethnic basis would engender a sense of discrimination. ${ }^{110}$ Curiously, the dissenting opinion also eschewed equal protection language. It did, however, express reminiscent outrage: "That law in this country should tolerate use of one's ancestry as probative of possible criminal conduct is repugnant under any circumstances." "111

INS agents have eagerly seized upon the Supreme Court's permission to use race as an indicator of illegal alienage. In United States v. Hernandez-Lopez, ${ }^{112}$ for example, where the driver was stopped for a traffic violation, agents claimed that their decision to question the passenger "sitting very rigidly in his seat" and "look[ing] like a Mexican cowboy" was reasonable. ${ }^{113}$ In United States $v$. Lopez-Barajas, ${ }^{114}$ agents justified their stopping a Hispanic disembarking from a plane on the grounds that he wore two-inch heels, dark green pants, and a blue-and-red-checked shirt, carried a garment bag, and retreated when a plainclothes agent stared at him. ${ }^{116}$ In United States $v$. Urias, ${ }^{116}$ agents stopped a man of Mexican ancestry because he turned off from a highway just prior to a checkpoint, as other aliens had done in the past. ${ }^{117}$ Courts approved those three detention decisions, but consistently have condemned more extreme reliance on ethnicity: United States $v$. Munoz $^{118}$ rejected the government's argument that reasonable suspicion was supplied by two cars traveling in tandem with a child in each front seat sitting between two Hispanic adults who failed to look at the agent; ${ }^{119}$ United States $v$. Pena-Contu ${ }^{120}$ held that adult Hispanic males sitting low in the back seat of a car of a type sometimes used by smugglers were detained improperly; ${ }^{121}$ and United States

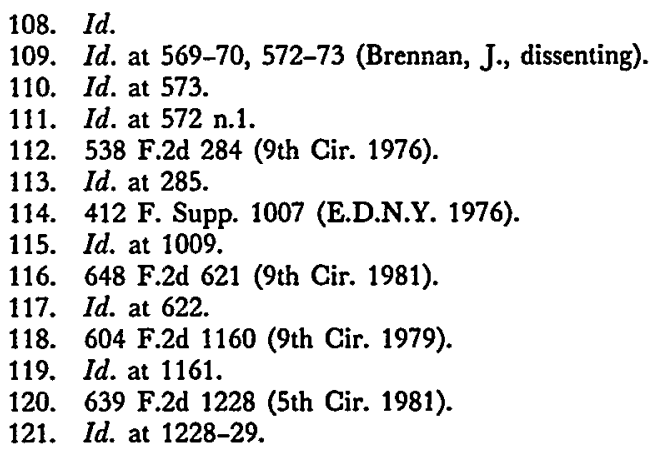


v. Mallides ${ }^{222}$ determined that six Hispanic males sitting "erectly" and not turning to look at a passing car did not give rise to reasonable suspicion. ${ }^{123}$

Despite the Supreme Court's cautionary footnote in Martinez-Fuerte, the INS has not restricted its use of Hispanic appearance to areas near the Mexican border. The response of the lower courts has been uneven. In Georgia, INS agents claimed that the defendant's Hispanic appearance contributed to their suspicion, but the suppression-hearing court rejected this claim based upon the 1000 miles separating the suspects and the Mexican border. ${ }^{124}$ In Chicago, American citizens of Mexican descent obtained an injunction against the INS to protect themselves from its excesses. The court's order enjoined detention of Hispanics absent "trustworthy tips or suspicious behavior," but made no mention of distance from the border. The plaintiffs' seven-year struggle to secure compliance from the INS continues. ${ }^{125}$ In New York Gity, INS agents detained three innocent Ecuadorian citizens legally residing in the United States and erroneously arrested one of them. ${ }^{126}$ The Ecuadorians' suit for damages failed. The court found a reasonable basis for a good faith belief that the plaintiffs' detention was proper from their ethnicity, their presence in Bay Ridge (allegedly an area with a fairly high concentration of illegal aliens), the fact that one of the three was carrying a lunch bag (thereby appearing to be on the way to work), and the fact that they spoke Spanish to each other. ${ }^{127}$

\section{Drug Courier Profiles}

The newest and most sophisticated use of race as a factor in probable cause determinations arises from the "drug courier profiles," developed for use at airports by the Drug Enforcement Agency (DEA). Many aspects of these profiles, including their inconsistencies, ${ }^{128}$ have generated contro-

122. 473 F.2d 859 (9th Cir. 1973).

123. Id. at 861. Other examples of unsuccessful INS attempts to use race to justify reasonable suspicion include United States v. Torres-Urena, 513 F.2d 540, 542 (9th Cir. 1975) (observation of Hispanic defendant loading boxes after sunrise at private home near border does not justify seizure); United States v. Martinez-Tapia, 499 F.2d 1244, 1245 (9th Cir. 1974) (observation of Hispanics in car accelerating on east-west California highway just past direct road leading south "often" used by smugglers insufficient basis for stop).

124. United States v. Gonzalez-Vargas, 496 F. Supp. 1296, 1299 (N.D. Ga. 1980).

125. Illinois Migrants Council v. Pilliod, 540 F.2d 1062, 1070 (7th Gir. 1976), modified, 548 F.2d 715 (7th Cir. 1977) (en banc).

126. Marquez v. Kiley, 436 F. Supp. 100 (S.D.N.Y. 1977).

127. Id. at 103-07.

128. The DEA apparently uses several profiles. See United States v. Elmore, 595 F.2d 1036, 1039 n.3 (5th Cir. 1979) (contrasting profile before court with one offered in earlier case of United States v. Ballard, 573 F.2d 913, 914 (5th Cir. 1978)); United States v. Rico, 594 F.2d 320, 325-26 (2d Cir. 1979) (noting that profile before court differs from that offered in Sixth Circuit). 
versy. ${ }^{129}$ For the most part, however, their racial component has not been explored. ${ }^{130}$

The precursor of the DEA profiles-the Federal Aviation Agency hijacking profile-did not employ race as a predictive factor. ${ }^{131}$ In an isolated case in which a supplemental memorandum to security personnel had added an ethnic element, the reviewing court rejected that element, noting the lack of an empirical basis and citing "serious equal protection problems."132 In another case approving the use of the FAA profile, Judge Friendly's concurrence noted the conditional nature of the approval: "Since all air passengers and their baggage can thus be constitutionally searched, there is no legal objection to searching only some . . . provided there is no national or racial discrimination without a rational basis (such as the destination of a particular flight)."13s

The response to race as a profile element has been different in the drug cases. Although the DEA has refused to commit the entire profile to writing, the profile clearly contains a racial component. Courts were initially reluctant even to acknowledge that aspect of the profile, but they have now approved it.

In 1977 , one agent testified that a factor in the profile was "people who are Hispanics (especially Mexicans)"134 and that he had relied on this factor when arresting the defendants. ${ }^{135}$ The Eastern District of New York denied a motion to suppress, apparently comforted that "the govern-

129. The Supreme Court heard two profile cases in 1980, Reid v. Georgia, 448 U.S. 438,441 (1980) (upholding police conduct in airport) (plurality opinion); United States v. Mendenhall, 446 U.S. 544, 558-59 (1980) (evidence demonstrated that defendant voluntarily consented to search, making search constitutional), and a third in 1982, Florida v. Royer, 103 S. Ct. 1319 (1983) (police officers illegally detained airline passenger without voluntary consent or reasonable suspicion).

Commentary on drug courier profiles is extensive. See, e.g., J. Choper, Y. KamiSar \& L. TRIBE, supra note 27, at 132-43; Note, Drug Courier Profile Stops and the Fourth Amendment: Is the Supreme Court's Case of Confusion In Its Terninal Stage?, 15 Sufrolk U.L. Rev. 217 (1981); Note, Drug Trafficking at Airports-The Judicial Response, 36 U. MIAMI L. REv. 91 (1981); Comment, Mendenhall and Reid: The Drug Courier Profile and Investigative Stops, 42 U. PITT. L. Rev. 835 (1981) [hereinafter cited as Comment, Mendenhall and Reid]; Comment, Criminal Profiles After United States v. Mendenhall: How Well-Founded A Suspicion?, 1981 UTAH L. REv. 557 [hereinafter cited as Comment, Criminal Profiles].

130. Two brief Comments regarding the ethnic elements of the profiles have been made. In one, the author of the Comment declared that one agent's mention of an ethnic element demonstrated that the agent did not understand the profile. Comment, Mendenhall and Reid, supra note 129, at 842. The other Comment merely voices a suspicion that race may be a profile element, then concludes that "an entirely separate equal protection question thus looms large." See Comment, Criminal Profiles, supra note 129 , at 561 .

131. See Fenello, Technical Prevention of Air Piracy, 585 InT'L Aviation 28, 31 n.6 (1971).

132. United States v. Lopez, 328 F. Supp. 1077, 1101 (E.D.N.Y. 1971).

133. United States v. Bell, 464 F.2d 667, 675 (2d Cir. 1972) (Friendly, J., concurring).

134. United States v. Westerbann-Martinez, 435 F. Supp. 690, 692 (E.D.N.Y. 1977).

135. Id. at 693 . 
ment did not, in its brief, press this point."138 The court then noted that "this factor does not tip the [Fourth Amendment] scales."137

In several later Second Circuit airport search cases, testimony that the defendant appeared to be Hispanic prompted no judicial comment. ${ }^{138}$ In his dissent in United States $v$. Vasquez, ${ }^{139}$ Judge Oakes asked for "assurances . . . that the rules were framed and enforced so as not to discriminate against any particular group on account of race, ethnic background, or the like."140 He explained, "One has the uncomfortable impression here that, but for the Hispanic appearance of Flores and Vasquez, they might not have been stopped."141 He further reasoned that United States v. Brignoni-Ponce ${ }^{142}$ would prohibit the use of race as "an overriding factor." 143 The majority responded to Judge Oakes's objection by characterizing the claim that Hispanic appearance played an impermissible role as "ambiguous at best,"144 and promised that any improper police conduct "must and will be condemned by this Court."145 It did not identify what might constitute "improper police conduct."

Finally, in a more recent-and more forthright-opinion addressing race and airport stops, the Second Circuit gave its approval:

Gradually various sets of circumstances deemed sufficiently objective and articulable in combination to justify a reasonable suspicion of unlawful activity were developed, with courts usually sympathetic toward upholding investigative stops on the basis of facts that would normally be viewed as innocent but for characterizations of government agents, including . . . [the suspect's] appearing to be a person of Hispanic background . . . ."146

In Michigan, the expected racial characteristics of drug couriers are different. In United States $v$. McClain, ${ }^{\mathbf{1 4 7}}$ a DEA agent explained that he too relied upon patterns in drug courier characteristics but that "[i]n the majority of cases the courier has been a black female."148 The reviewing court did not comment on this assertion. Perhaps coincidentally, United

136. Id. at 700 n.11.

137. Id.

138. See United States v. Vasquez-Santiago, 602 F.2d 1069, 1070 (2d Cir. 1979), cerl. denied, 447 U.S. 911 (1980); United States v. Rico, 594 F.2d 320, 322 (2d Cir. 1979).

139. 612 F.2d 1338 (2d Cir. 1979), cerl. denied, 447 U.S. 907 (1980).

140. Id. at 1352 (Oakes, J., dissenting).

141. Id. at $1352-53$.

142. 422 U.S. 873 (1975).

143. United States v. Vasquez, 612 F.2d at 1353 (Oakes, J., dissenting).

144. Id. at 1346 (majority opinion).

145. Id.

146. United States v. Place, 660 F.2d 44, 48 (2d Cir. 1981).

147. 452 F. Supp. 195 (E.D. Mich. 1977).

148. Id. at 199. 
States $v$. Mendenhall, ${ }^{149}$ the first drug courier profile case decided by the Supreme Court, involved a black female defendant stopped in Detroit, Michigan. A majority of the Court found inadequate grounds for a stop; ${ }^{180}$ race as an explanation for the action was neither pressed by the government nor discussed by the Court.

\section{E. General Criminal Propensity}

There is substantial evidence that many police officers believe minority race indicates a general propensity to commit crime. The evidence further suggests the police weigh that belief in their decisions to detain. ${ }^{151}$ If that generalization is made explicit, courts uniformly reject it, usually relying on the Fourth Amendment. United States $v$. Robinson ${ }^{162}$ dismissed an officer's claim that a new automobile in a black neighborhood provided a basis for reasonable suspicion; United States $v$. Nicholas ${ }^{163}$ invalidated a stop based on the supposition that any black driver with out-of-state license plates was suspicious; and United States $v$. Carrizoza-Gaxiola ${ }^{164}$ rejected Mexican ancestry as probative of stolen vehicle transportation.

One court responded with a Fourteenth Amendment analysis to a particularly blatant use of racial propensity. The Pennsylvania State Police issued a directive to banks, which stated in part:

\section{BANK INFORMATION}

Take photos of any black males or females coming into bank who may look suspicious:

A. Come in to ask directions.

B. Exchange large bills for small money.

C. Come in for no apparent reason.

NOTIFY LOCAL OR STATE POLICE. ${ }^{185}$

In a civil suit by a photographed black customer, the Third Circuit ruled that these facts stated a cause of action under federal civil rights acts and

149. 446 U.S. 544 (1980).

150. The Court sustained the DEA agent's activity only because two justices concluded that Mendenhall had not been seized, id. at 555-60 (Stewart \& Rehnquist, JJ.), and three justices concluded that there was reasonable suspicion to justify the seizure, id. at 565-66 (Powell, J., Burger C.J. \& Blackmun, J., concurring).

151. See, e.g., L. Tiffany, D. McIntyre \& D. Rotenberg, supra note 19, at 20-21; M. Wolfgang \& B. Cohen, CRIme and Race 69-72 (1970); Hepburn, Race and the Decision to Arrest: An Analysis of Warrants Issued, 15 J. Research CRIME \& Deling. 54 (1978); Piliavin \& Briar, Police Encounters with Juveniles, 60 AM. J. Soc. 206 (1964); see also Griswold, Police Discrimination: An Elusive Question, 6 J. PolICE SCI. \& ADMIN. 61 (1978) (discussing various contradictory findings).

152. 535 F.2d 881, 884 (5th Cir. 1976).

153. 448 F.2d 622, 625-26 (8th Cir. 1971).

154. 523 F.2d 239, 241 (9th Cir. 1975).

155. Hall v. Pennsylvania State Police, 570 F.2d 86, 88 (3d Cir. 1978). 
remanded for trial. ${ }^{158}$ The court distinguished the use of race to identify a particular perpetrator from this "form of criminal investigation directed against the plaintiff because of his race," holding that the latter violated the guarantee of equal protection of the law. ${ }^{157}$

\section{The Unconstitutionality of GurRent Uses of Race}

No fact should weigh in the probable cause or reasonable suspicion mix unless its use satisfies both Fourth Amendment probabilistic constraints and Fourteenth Amendment equal protection constraints. Judicial acceptance of the use of race as a factor which elevates suspicion generally disregards the nature of probable cause and reasonable suspicion, the guarantee of equal protection of the laws, or both.

\section{A. Probabilistic Constraints on the Use of Race}

By definition, race cannot affect probable cause or reasonable suspicion calculations unless it is statistically related to suspected criminal activity. Nevertheless, courts have approved or disapproved the various uses of race without requesting evidence on the correlation between race and crime.

\section{General Criminal Propensity}

To begin, we can ask whether, ceteris paribus, a black or Hispanic (or Asian or white) person is more likely to engage in crime than is a random member of the general population. This is a logical place to start, both because more data have been collected on this question than on several of the more particularized empirical propositions about race and criminal activity, and because the conceptual problems introduced here provide a paradigm for later consideration of the more specialized uses of race.

Certainly, if we consider all kinds of criminal activity, including whitecollar crime, the proportionate involvement of any racial group is speculative. ${ }^{158}$ Arrest records on common law or street crimes-those that the policeman on the beat would most often consider-show that blacks are vastly over-represented, although such over-representation has a number of potential explanations. To the extent that arrest data reflect selection biases of the criminal justice system, rather than disproportionate involvement, ${ }^{109}$ considering race in the decision to detain would be illogical and circular. A second measurement technique, self-report studies, shows

156. Id. at 92 .

157. Id. at 91 .

158. Sep C. Silberman, supra note 36 , at 41-47.

159. See Hindelang, Race and Involvement in Common Law Personal Crimes, 43 AM. Soc. Rev. 93, 94-107 (1978) (discussing studies). 
negligible racial differences in criminal involvement, thus suggesting a selective processing interpretation of the arrest data. ${ }^{160}$ Finally, surveys of victims show disproportionate black involvement as well as biased processing. ${ }^{161}$

Each of these data sources is methodologically flawed. ${ }^{162}$ Consequently, scholars disagree on the extent to which arrest rates should be attributed to differential involvement or to differential processing. ${ }^{163}$ Still, this dispute is not fatal for the use of race as a general indicator of propensity. Since most experts agree that disproportionate involvement explains some of the arrest statistic differential, race properly may be considered as $a$ factor. The problem is that we cannot say with any confidence how much weight should be attached to it.

Moreover, there may be a "double-counting" problem. Whatever degree of differential involvement exists undoubtedly results in large part from socio-economic factors. ${ }^{104}$ This in itself would not prohibit the use of race as a detention factor, at least not as a definitional matter. If, however, a large share of disproportional involvement is attributable to poverty and differential association, ${ }^{165}$ race will not predict criminal activity when those factors are controlled for. Because poverty and differential association opportunities probably coincide quite nicely with "crime-prone neighborhoods," race may add little or no predictive power if a police officer has already weighed the nature of the neighborhood.

In addition, police may be double counting because they have already considered the suspiciousness of conduct indicating consciousness of guilt. There are reasons to believe that race may actually diminish the predictive power of such observations. Studies show that nonverbal cues, including eye contact, posture, and body movement, vary among subcultures. ${ }^{188} \mathrm{Be}-$ havior that reflects consciousness of guilt among the dominant culture-of which the officer usually is a member-may reflect only an ethnic difference when displayed by a minority group member. ${ }^{187}$ Thus, for an officer

160. See C. Owens, Mental Health and Black Offenders (1980); Hindelang, supra note 159, at 94-96; McNelly \& Pope, Race and Involvement in Common Law Personal Crime: $A$ Response to Hindelang, 8 Rev. BLACK PoL. EcoN. 405 (1978).

161. See Hindelang, supra note 159 , at $96-97$ (summarizing studies).

162. See id. at 97-101 (analyzing victim survey data).

163. See McNelly \& Pope, supra note 160 , at 405-06.

164. Id. at 407-08.

165. Differential association theory posits that criminality is not primarily caused by biological deficiency or psychological abnormality, but is learned through association with criminals. With greater frequency and consistency of association with criminals, a person is more likely to adopt criminal values and learn criminal techniques. See The Professional. Thief 206-09 (E. Sutherland ed. 1937); E. Sutherland, White Collar Crime 240-63 (Yale Univ. ed. 1983).

166. See M. Argyle, Bodily Communication 73-105 (1975); E. Hall, The Hidden Dimension (1966); E. Hall, The Silent Language (1959); Ekman, Universal and Cultural Differences in Facial Expressions of Emotion, in Nebraska Symposium on Motivation (1972).

167. See Cassata, Nonverbal Behavior and Law Enforcenent: The Hidden Cues, 6 J. Pource 
to "add" the predictive power of race to the predictive power of a furtive gesture may be illogical; minority race may actually subtract from the predictive value of the furtive gesture.

One recent study found that blacks are disproportionately the victims of arrests not supported by probable cause. ${ }^{168}$ Whatever the general predictive power of race, this study suggests that, for various reasons, police overestimate it. Although probabilistic constraints may not preclude consideration of general racial propensities to commit crime, they clearly militate against according them substantial weight.

\section{Identification of a Particular Offender}

When race is used merely as an element in the description of a particular perpetrator, of course, no probabilistic problems occur. The proposition that more congruent details increase the likelihood of identity between suspect and perpetrator seems indisputable. Such self-evident propositions do not require statistical proof since probable cause is a "common sense" concept. ${ }^{168}$

\section{Illegal Aliens}

The use of race as a detention factor in suspected immigration law violations also generally complies with probabilistic constraints. The Immigration and Naturalization Service (INS) collects extensive statistics on illegal aliens and has presented them to the courts. These statistics show that although Hispanics are only a small fraction of the total population of the United States, more than eighty-five percent of arrested aliens are of Mexican descent. ${ }^{170}$ Selective processing may explain some of the disproportionate arrest rate, but no one denies that the bulk of the discrepancy results from differential involvement.

One conceptual difficulty not resolved by the otherwise compelling INS statistics is whether Hispanic appearance adds to the suspicion prompted by "furtive gestures." Perhaps as a result of cultural differences, white agents may perceive normal Hispanic behavior and body movements as guilt-ridden. In light of the heavy reliance placed upon furtive gestures in many immigration cases, testimony on cultural differences-or the lack thereof-seems desirable. ${ }^{171}$

\footnotetext{
SCI. \& AD. 10, 14-16 (1978).

168. Sep Hepburn, supra note 151 , at 59,66 .

169. Sep supra pp. 217-19.

170. See United States v. Ortiz, 422 U.S. 891, 901 (1975) (appendix to opinion of Burger, C.J.).

171. Evidence of such cultural differences might suggest that courts should reject the probative value of the "furtive gestures" rather than the probative value of race.
} 


\section{Drug Courier Profiles}

In contrast to the extensive documentation from the INS, no data have been offered to support drug courier profiles. Because the DEA has not released the statistics upon which its profile is based, courts have no basis for determining either the statistical significance or the strength of the asserted correlation between race and drug courier activity. Should the DEA reveal its arrest statistics, courts still would not know whether those statistics reflected racially selective investigation by the DEA or the asserted disproportionate racial involvement. Unless the DEA provides corroborating self-report or victimization studies for narcotics traffic, attribution of any differences in arrest rates to differential involvement would be unwarranted. Indeed, there is some support for the alternative hypothesis that arrest rates reflect racially selective processing. That some agents have observed the couriers to be predominantly Hispanic, while others have observed them to be almost exclusively black females, suggests a selffulfilling prophecy. ${ }^{172}$ Agents who look for Hispanic drug couriers find them, and agents who lie in wait for black females do not arrest white males. Of course, these are not insuperable barriers. If the data are as compelling as the DEA would like the courts to believe, the ethnic element in drug courier profiles may satisfy probabilistic constraints. But unless and until the government provides such data, courts should ignore race when assessing the justification for the detention of a suspected drug courier.

\section{Incongruity}

Assertions that racial incongruity increases suspicion create even greater tension with the concepts of probable cause and reasonable suspicion. In most incongruity cases, an officer will testify simply that persons of the suspect's race are rarely seen in the neighborhood in which the suspect was found. Because the infrequency of an event reveals nothing about its correlation with criminal activity, such testimony is irrelevant to a determination of probable cause or reasonable suspicion.

\footnotetext{
172. One commentator has observed:

The police's propensity to regard the culturally different with suspicion fosters sharper and increased surveillance of cultural minorities and minority communities. Police sterectyping of cultural minorities not only increases the suspicion and surveillance, but also serves as a selffulfilling prophecy. Thus when the police note, in statistical reports, that the arrest incidence of Indians for offenses involving drunkenness is several times that for the United States as a whole, they are more prone to look for evidence of drunkenness in cases involving Indians and to see sufficient evidence to warrant arrest.
}

Swett, Cultural Bias in the American Legal System, 4 LAw \& Soc'y REv. 79, 93 (1969) (citations omitted). 
More complex are incongruity cases in which the officer further testifies that most (or all) persons of the suspect's race appearing in that neighborhood were engaged in illegal activity. If the officer has observed only one other black person in the area and that person was committing a crime, his isolated observation may be a fluke; the sample size is too small to conclude that the correlation is not spurious. An inference of predictive power would be justified only when the arresting officer testifies to observations (his own or those of fellow officers) that are sufficiently numerous to reveal a pattern. When this condition is met, probabilistic constraints are satisfied.

\section{B. Equal Protection Constraints}

Whether or not the use of race in detention decisions is consistent with the goals of the Fourth Amendment, it also must be tested against the stringent standards of the Fourteenth Amendment. Racial classifications are subject to "the most rigid scrutiny,"173 and demand a "very heavy burden of justification."174 If this scrutiny is directed at the expanding use of race as a factor in probable cause and reasonable suspicion determinations, one can only conclude that factual guilt has blinded many courts to equal protection violations.

\section{The Purposefulness of Detention Decisions Based on Race.}

That detention decisions are made by police officers and evaluated by courts does not insulate them from equal protection scrutiny: Executive, ${ }^{175}$ administrative, ${ }^{178}$ and judicially enforced private ${ }^{177}$ classifications based upon race are subject to the same constraints as those promulgated by legislatures.

Most cases involving executive or administrative classifications have concerned facially neutral policies alleged to be discriminatory in effect. In these "disproportionate impact" cases, the Supreme Court has stressed that "the invidious quality of a [government action] claimed to be racially discriminatory must ultimately be traced to a racially discriminatory pur-

173. Strauder v. West Virginia, 100 U.S. 303, 310 (1880) (invalidating exclusion of blacks from juries).

174. Loving v. Virginia, 388 U.S. 1,9 (1967) (striking down anti-miscegenation statute).

175. See Korematsu v. United States, 323 U.S. 214 (1944) (military order excluding all persons of Japanese ancestry from designated West Coast areas); Hirabayashi v. United States, 320 U.S. 81 (1943) (West Coast curfew on persons of Japanese ancestry).

176. See Yick Wo v. Hopkins, 118 U.S. 356 (1886) (municipal ordinance prescribing kind of building in which laundries may be located).

177. See Shelley v. Kraemer, 334 U.S. 1 (1948) (restrictive covenant excluding persons of designated races from owning or occupying real property). 
pose."178 A showing of animus supplies the "discriminatory purpose" in cases alleging disproportionate impact, but this showing is necessary only because the statute or regulation is facially neutral. When governmental action on its face disadvantages racial or ancestral minorities, this is by definition "discriminatory" regardless of the purported motivation; ${ }^{179}$ no Supreme Gourt precedent or dictum concerning an explicit classification disadvantaging a racial minority requires proof of illicit or irrational motivation to trigger strict scrutiny. ${ }^{\mathbf{1 8 0}}$

Nevertheless, the government's argument in Martinez-Fuerte ${ }^{\mathbf{1 8 1}}$ and Brignoni-Ponce ${ }^{\mathbf{1 8 2}}$ assumed that administrative classifications required proof of racial hostility before strict scrutiny would be invoked. ${ }^{183}$ The only commentary on these cases considering the equal protection issue agrees that lack of racial animus renders the use of race "nondiscriminatory."184 Were this view correct, no statistically supported use of race in detention decisions would be subject to strict scrutiny. The motive for its use would not be racial hostility, but effective law enforcement. This reading not only misconstrues the Court's "discriminatory purpose" requirement; it stands the history of the equal protection clause on its head. Because a primary purpose of the Fourteenth Amendment was to free blacks from stereotypes, prompted by a history of disadvantage and slavery that ignored the qualities of the individual, it would be astonishing if accurate stereotypes foreclosed heightened judicial scrutiny. Legitimate purposes and their statistical support may be relevant to the constitutionality of explicit racial classifications, but only as they contribute to meeting "the heavy burden of justification," not as to whether that burden should be imposed.

\section{a. Identification of a Particular Offender}

The appropriateness of heightened judicial scrutiny depends upon how race is used in detention decisions. The use of race to identify a particular perpetrator, for example, does not disadvantage any racial group and thus

178. Washington v. Davis, 426 U.S. 229, 240 (1976); see Village of Arlington Heights v. Metropolitan Hous. Dev. Corp., 429 U.S. 252, 265-66 (1977); Snowden v. Hughes, 321 U.S. 1, 8-9 (1944).

179. Sep Washington v. Seattle School Dist. No. 1, 102 S. Ct. 3187, 3202-03 (1982).

180. Id.

181. 428 U.S. 543 (1976).

182. 422 U.S. 873 (1975).

183. See supra p. 232. This also seems to be the view taken by the district court in United States v. Lopez, 328 F. Supp. 1077 (E.D.N.Y. 197.1), discussed supra p. 234. The court stressed that the "ethnic element" of the altered profile employed by the airline was not statistically supported and implied that it was this irrationality that raised the equal protection issues. Id. at 1101 .

184. See Note, Minority Groups and the Fourth Amendmenl Standard of Certitude: United States v. Ortiz and United States v. Brignoni-Ponce, 11 HARv. C.R.-C.L. L. REv. 733, 735 n.10 (1976). 
does not require strict scrutiny. Although the suspect's race is noted and weighed in the decision to detain, no generalizations about the characteristics, behavior, or appropriate treatment of the racial group are employed. Rather, the suspect's race is used solely to help substantiate his identity as the individual involved in a particular offense. Because suspects in all racial groups will be identified in part by their race, reliance upon the witness's description of the perpetrator's race seems to impose equal burdens on all races.

Absent discriminatory effects, provisions for racial designations do not require strict scrutiny. ${ }^{185}$ At least in theory, the use of race to help identify a particular perpetrator is neutral in both design and effect. ${ }^{188}$ Only if the racial description of particular perpetrators is used disingenuously (for example, as an excuse for law enforcement officers to "hassle" members of a disfavored racial group) would a disadvantaging racial classification be at issue and strict scrutiny be required.

\section{b. Illegal Aliens, Drug Courier Profiles, and General Criminal Propensity}

The three other uses of race in decisions to detain indisputably involve facially discriminatory classifications, however, and should be subject to strict scrutiny. First, the INS's reliance on Hispanic appearance in the illegal alien cases intentionally singles out Hispanics as a group. Second, the DEA's reliance on race in drug courier cases singles out Hispanics as a group when they travel in New York, and blacks as a group when they travel in Michigan. Third, the disapproved police practice of relying on race as a factor in street crime detentions disadvantages blacks as a group. That race is only one factor in these detention decisions does not alter the equal protection analysis. ${ }^{187}$ Because an explicit racial classification contributes to the decision to impose a substantial unpleasant consequence, ${ }^{\mathbf{1 8 8}}$ strict scrutiny is required.

185. When a state statute requiring recitation of the spouses' race in divorce decrees was challenged, the Supreme Court upheld it. The district court had stated that "the securing and chronicling of racial data for identification or statistical use violates no constitutional privilege." Hamm v. Virginia State Bd. of Elections, 230 F. Supp. 156, 158 (E.D. Va.) (emphasis added), aff'd per curiain sub nom. Tancil v. Woolls, 379 U.S. 19 (1964).

186. But of. Anderson v. Martin, 375 U.S. 399, 403 (1964) (striking down Louisiana statute requiring designation of candidates' race on nomination petitions and ballots because it encouraged voting along racial lines).

187. Sep Village of Arlington Heights v. Metropolitan Hous. Dev. Corp., 429 U.S. 252, 265-66

(1977) (if race is a motivating factor in decision then choice presumed to be illegitimate).

188. Even the limited intrusion of a stop and frisk involves more than de minimis consequences:

It must be recognized that whenever a police officer accosts an individual and restrains his freedom to walk away, he has "seized" that person. . . . Moreover, it is simply fantastic to urge that such a procedure performed in public by a policeman while the citizen stands helpless, perhaps facing a wall with his hands raised, is a "petty indignity." It is a serious intru- 


\section{c. Incongruity}

Finally, the use of racial incongruity should be subject to strict scrutiny. Racial incongruity is particularly troublesome because its justification recalls the rationale for segregatory legislation: Segregation does not violate the Fourteenth Amendment because it imposes symmetrical burdens on each group. ${ }^{189}$ The use of racial incongruity is purportedly justified because blacks face increased suspicion if they venture into white neighborhoods while whites face increased suspicion if they venture into black neighborhoods.

Until 1954, the "separate but equal" vision of Plessy v. Ferguson sanctioned most reciprocal restrictions. ${ }^{190}$ Brown $v$. Board of Education's ${ }^{191}$ rejection of segregated schools foreshadowed the total rejection of the symmetrical burden doctrine. McLaughlin v. Florida ${ }^{192}$ overturned a state law forbidding interracial cohabitation. The Court stated:

Judicial inquiry under the Equal Protection Clause, therefore, does not end with a showing of equal application among the members of the class defined by the legislation. The courts must reach and determine the question whether the classifications drawn in a statute are reasonable in light of its purpose-in this case, whether there is an arbitrary or invidious discrimination between those classes covered by Florida's cohabitation law and those excluded. ${ }^{193}$

Such a law could be upheld only if it was necessarily-not merely rationally-related to the achievement of a valid state interest. ${ }^{104}$ McLaughlin, however, reserved the question of whether prevention of miscegenation was a legitimate state purpose. In Loving $v$. Virginia, ${ }^{105}$ the Court responded to a direct challenge of a law forbidding interracial marriages:

The statutes proscribe generally accepted conduct if engaged in by members of different races. Over the years, this Court has consistently repudiated "[d]istinctions between citizens solely because of their ancestry" as being "odious to a free people whose institutions

sion upon the sanctity of the person, which may inflict great indignity and arouse strong resentment, and it is not to be undertaken lightly.

Terry v. Ohio, 392 U.S. 1, 16-17 (1968).

189. See Plessy v. Ferguson, 163 U.S. 537, 551-52 (1896) (applying separate but equal rationale to segregation of public transportation facilities).

190. See Cumming v. Richmond County Bd. of Educ., 175 U.S. 528, 544-45 (1899) (applying Plessy to segregated education); see generally C. Woodward, The Strange Career of Jim Crow (3d ed. 1974) (discussing history of legalized segregation in the South).

191. 347 U.S. 483 (1954).

192. 379 U.S. 184 (1964).

193. Id. at 191 .

194. Id. at 196.

195. 388 U.S. 1 (1967). 
are founded upon the doctrine of equality." . . W We have consistently denied the constitutionality of measures which restrict the rights of citizens on account of race. There can be no doubt that restricting the freedom to marry solely because of racial classifications violates the central meaning of the Equal Protection Clause. ${ }^{198}$

Using race to justify detaining blacks in white neighborhoods and whites in black neighborhoods seems to fall within the prohibition of McLaughlin and Loving. The substantive rights at issue are again associational. McLaughlin concerned the persons with whom one lived, Loving involved the person whom one married, and deeming race suspicious in a neighborhood concerns the persons one visits.

There are differences, of course. Both Loving and McLaughlin involved racial classifications in a criminal statute, which are "especially suspect" state action. ${ }^{197}$ In addition, the laws overturned in Loving and McLaughlin were obviously "designed to maintain White Supremacy." ${ }^{198}$ Nevertheless, using racial incongruity as a factor in determining probable cause should also be subject to strict scrutiny. Although this use of race may be superficially neutral, it functions in practice to disadvantage minorities. Because there are far more predominantly white than predominantly black neighborhoods, a black person has many fewer areas in which he may travel without prompting suspicion and possible detention. Furthermore, because many black neighborhoods are poor, have limited public recreation facilities, and have higher crime rates than white neighborhoods, it would be unusual for a white person to want to enter many of these neighborhoods except to visit a particular person. It would be much more likely that a black person would want to enter a white area, many of which are aesthetically pleasant, contain the most desirable public recreation facilities, and benefit from better public safety services. Thus, blacks would be detained because their race was "out of place" more often than would whites, and blacks would be inhibited in their choices of where to travel more often than would whites.

Even if it were not more burdensome to blacks than to whites, police action based upon racial incongruity should invoke strict scrutiny because it fosters racial separation. Stopping blacks in white neighborhoods and whites in black neighborhoods when their conduct alone does not justify detention will discourage people from socializing or living outside their own racial group, possibly conveying social stigma and fostering stereotypes. "Few principles of law are more firmly stitched into our constitu-

196. Id. at 11-12.

197. Id. at 11 .

198. Id. 
tional fabric than the proposition that a State must not discriminate against a person because of his race or the race of his companions, or in any way act to compel or encourage racial segregation." tion of police actions clearly influenced by "out of place" racial minorities will deter interracial socialization. Allowing police to stop blacks in predominantly white neighborhoods will also deter residential integration. It will send an implicit message to blacks that their decision to live in previously white areas is unwelcome.

\section{Application of the Strict Scrutiny Standard}

With the exception of race as an identifying feature, therefore, each of the uses of race as a factor in the decision to detain should be subjected to the most searching scrutiny. Such examination does not compel a finding of unconstitutionality, but as Professor Gunther neatly put it, such scrutiny is "strict" in theory and "fatal" in fact. ${ }^{200}$

The Supreme Court has only once upheld an explicit non-remedial racial classification to which it had applied strict scrutiny. ${ }^{201}$ In Korematsu v. United States, ${ }^{202}$ the Court sustained a military order excluding persons of Japanese ancestry from designated West Coast areas after Pearl Harbor. Justice Black's analysis required a "[p]ressing public necessity" to justify a racial classification. ${ }^{203} \mathrm{He}$ found that necessity in the military authority's belief that an unascertained number of Japanese-Americans were disloyal and had to be immobilized immediately. ${ }^{204}$ The exclusion was justified

because we are at war with the Japanese Empire, because the properly constituted military authorities feared an invasion of our West Coast and felt constrained to take proper security measures, because

199. Adickes v. S.H. Kress \& Co., 398 U.S. 144, 150-52 (1970) (emphasis added) (finding that such discrimination might be involved in arrest of white woman participating in sit-in at lunch counter); see Trafficante v. Metropolitan Life Ins. Co., 409 U.S. 205, 212 (1972) (granting standing to sue to white tenants when discriminatory renting practices deny them benefits of living in integrated community).

200. Gunther, The Supreme Court, 1971 Tern-Foreword: In Search of Evolving Doctrine on a Changing Court: A Model for a Newer Equal Protection, 86 HARv. L. REv. 1, 8 (1972).

201. Spe Fullilove v. Klutznick, 448 U.S. 448 (1980) (upholding 10\% set-aside of construction funds for minority businesses).

The classifications at issue in this Article are certainly not remedial. Nor can they be considered "benign" in a more general way, given widespread minority hostility toward the police. See Jacobs \& Cohen, The Impact of Racial Integration on the Police, 6 J. Police ScI. \& AD. 168, 168-71 (1978) (reviewing literature on black sentiment toward police).

202. 323 U.S. 214 (1944); see also Hirabayashi v. United States, 320 U.S. 81 (1943) (upholding earlier West Coast military curfew on persons of Japanese ancestry without explicating standard of review).

203. 323 U.S. at 216.

204. Id. at 218-19. 
they decided that the military urgency of the situation demanded that all citizens of Japanese ancestry be segregated from the West Coast temporarily, and finally, because Congress, reposing its confidence in this time of war in our military leaders-as inevitably it must-determined that they should have the power to do just this. ${ }^{205}$

Three Justices dissented, ${ }^{208}$ and Korematsu has since been excoriated by many. ${ }^{207}$ Whether or not Korematsu simply sanctioned congressional prejudice or was justified by military exigencies, none of the uses of race as a factor in detention decisions is analogous. Neither the military urgency of wartime nor the imprimatur of Congress justifies acceptance of the classifications at issue in detention decisions.

\section{a. The Compelling State Interest Requirement}

Korematsu's focus on the importance of the ends served by a racial classification has often been reiterated ${ }^{208}$ The law enforcement interests at stake in detention decisions cannot meet Korematsu's "pressing public necessity" standard or its modern equivalent, the "compelling state interest" requirement.

A determination of compelling state interest requires an examination of the alternatives to the practice under scrutiny. In many detention decisions, the alternative to partial reliance on race is continued police surveillance. That surveillance will often uncover additional, non-invidious reasons for suspicion. Police must tolerate the consequent delay and diminished efficiency; administrative convenience can never provide the requisite compelling state interest. ${ }^{200}$ When non-invidious predictors are

205. Id. at 223 .

206. Id. at 225-33 (Roberts, J., dissenting); id. at 233-42, (Murphy, J., dissenting); and id. at 242-48 (Jackson, J., dissenting).

207. See, e.g., M. Grodzins, Americans Betrayed: Polmtics and the Japanese EvacuaTION (1949); Dembitz, Racial Discrimination and the Military Judgment: The Supreme Court's Korematsu and Endo Decisions, 45 Colvm. L. Rev. 175 (1945); Freeman, Genesis, Exodus, and Leviticus: Genealog;, Ez'acuation, and Law, 28 CoRnELl. L.Q. 414 (1943); Rostow, The Japanese American Cases-A Disaster, 54 Yale L.J. 489 (1945). But see DeFunis v. Odegaard, 416 U.S. 312, 339 n.20 (1974) (Douglas, J., dissenting) (defending Korematsu).

208. In McLaughlin v. Florida, 379 U.S. 184 (1964), for example, Justice White's majority opinion looked for evidence of "some overriding statutory purpose requiring the [racial classification]. . . "Id. at 192. In Loving v. Virginia, 388 U.S. 1 (1967), Chief Justice Warren found "no legitimate overriding purpose." Id. at 11. Eisenstadt v. Baird, 405 U.S. 438 (1972), noted that racial classifications must be "necessary to the achievement of a compelling state interest." Id. at $447 \mathrm{n} .7$ (emphasis in original). More recently, opinions on both sides of the dispute about racial classifications designed to remedy past discrimination have assumed that non-remedial racial classifications are valid only in the presence of a compelling state interest. Compare Fullilove v. Klutznick, 448 U.S. 448, 496 (1980) (Powell, J., concurring) (compelling state interest required for all racial classifications) with Regents of Univ. of Cal. v. Bakke, 438 U.S. 265, 357, 361 (1978) (Brennan, White, Marshall, and Blackmun, JJ.) ("compelling governmental purpose" required for racial classifications which stigmatize, but "important governmental objective" sufficient to justify remedial racial classifications).

209. Cf. Frontiero v. Richardson, 411 U.S. 677, 690 (1973) (Brennan, J.) (administrative con- 
available, there can be no compelling state interest in using racial classifications. ${ }^{210}$

Where no non-invidious information is discovered, disregard for the predictive value of race will result in no detention, either because no further observation is possible or because further observation reveals only innocuous information. In some of these cases, the "loss" of a stop or arrest is a gain. The police will observe no further suspicious factors because there is no underlying illegal activity. In other cases, a guilty person will remain at large because race is not used. With the exception of the illegal alien cases, the government has not documented either the relative frequency of these two situations or the absolute frequency of the latter situation. In my estimation, the number of guilty drug couriers, black street criminals, or racially out-of-place suspects who will permanently escape police intervention if race is not considered in detention decisions will be small indeed. Conversely, I believe that a large number of innocent minority-group members will be saved from harassment stemming from an exaggerated sense of the predictive power of race. ${ }^{211}$ Because "the heavy burden of justification" falls on the government, an unsubstantiated and speculative interest in law enforcement cannot be counted as a compelling state interest.

Immigration laws, of course, are distinguished by the strength of the data amassed by the INS. Although only a small fraction of the population is Hispanic, eighty-five percent of illegal aliens are Hispanic. ${ }^{212}$ These numbers permit the inference that the elimination of race as a probative factor would result in a significant reduction in the number of arrests of illegal aliens. The inference is not unassailable because we do not know the proportion of cases in which continued surveillance would uncover other predictive factors justifying detention. However, if the INS's use of Hispanic appearance is limited to areas near the Mexican border, as the Court's opinion in Martinez-Fuerte suggested it should be, ${ }^{213}$ then

venience alone cannot justify dissimilar treatment of men and women); Reed v. Reed, 404 U.S. 71, 76-77 (1971) (same).

210. The experience of those who construct predictors for parole success is instructive. Peter Hoffman, principal designer of the federal parole guidelines, asserts that when an inmate's prior criminal record and other non-racial factors are used to predict criminal recidivism, race adds very little predictive power. See Project, Parole Release Decisionmaking and the Sentencing Process, 84 YALE L.J. 810, 877 n.329 (1975); see also Underwood, Law and the Crystal Ball: Predicting Behavior with Statistical Inference and Individualized Judgment, 88 YALE L.J. 1408, 1434-36 (1979) (criticizing use of race as predictive factor because of inaccuracy, cumulative discriminatory effect, and threat to individual autonomy).

211. For one man's story of repeated police abuse of race as a detention factor, see Lawson v. Kolender, 658 F.2d 1362, 1363 (9th Gir. 1981), aff'd, 103 S. Ct. 1855 (1983).

212. See United States v. Ortiz, 422 U.S. 891, 901 (1975) (appendix to opinion of Burger, C.J.).

213. See United States v. Martinez-Fuerte, 428 U.S. 543, 559-64 (1976). 
we can reasonably assume that there are too many "suspicious" Hispanics to make continued observation of all of them possible.

But proof that elimination of this racial classification would substantially (or even drastically) reduce arrests of illegal aliens clears only the first hurdle. The government must further prove that increasing the number of arrests promotes a pressing public necessity. This it cannot do. It is not clear that the hordes of aliens who cross our borders injure the domestic economy. ${ }^{214}$ Even if illegal migration does result in job losses for the domestic labor force or increased social welfare expenditures, elimination of those injuries is not even remotely as compelling as the prevention of sabotage during wartime, the one justification that the Court has accepted for using explicit racial classifications. Finally, the use of race in detention decisions has woefully failed to prevent these injuries. ${ }^{215}$ In light of this failure, the government's neglect of other means to curb illegal immigration casts doubt on the sincerity of any claim that a compelling interest is involved. For example, although the dominant incentive for illegal entry is the availability of employment, the government does not prohibit the employment of illegal aliens. ${ }^{216}$ The government could also increase the line watch personnel who cover the border itself and stop all persons who cross from one zone into the other. ${ }^{217}$ The courts certainly should not consider a governmental interest compelling until the government itself does.

\section{b. The Necessary Means Requirement}

In conventional equal protection analysis, we could stop after finding the governmental interests advanced by the discrimination to be less than compelling. Although strict scrutiny further demands a "necessary" or "precisely tailored" means, ${ }^{218}$ investigation of the fit between means and ends is unnecessary if the end is not a compelling governmental interest.

Despite the Court's statement of the ends and means requirements as conjunctive, a few commentators have argued that the strict scrutiny standard should focus only on the fit between ends and means:

[T]he goal served by the classification need only be permissible, not

214. See Plyler v. Doe, 457 U.S. 202, 228 (1982) ("There is no evidence in the record suggesting that illegal entrants impose any significant burden on the State's economy. To the contrary, the available evidence suggests that illegal aliens underutilize public services, while contributing their labor to the local economy and tax money to the state fisc.").

215. Id. at 218 n.17 (estimate by Attorney General of between three million and six million illegal aliens in United States).

216. Id. at 218-19.

217. But see United States v. Ortiz, 422 U.S. 891, 908 (1975) (appendix to opinion of Burger, C.J.) (arguing that increased manpower would not increase effectiveness of line watch and Border Patrol).

218. Plyler v. Doe, 457 U.S. 202, 216-17 (1982). 
compelling. Thus, if the classification is perfect [or justified in its imperfections by exigent circumstances], the reviewing court should not proceed to inquire into how compelling the asserted state interest is. Although some might think such substantive testing desirable, the Court does not appear in its holdings to have committed itself to test for a compelling state interest. ${ }^{219}$

In this view, Korematsu permitted an imperfect classification only because the exigencies of war precluded a perfect classification.

The ultimate outcome of this debate, however, will not affect the use of race in detention decisions. A doctrinal shift in emphasis from the nature of the interest to the perfection of the classification may facilitate an expansion of the number of suspect classifications, ${ }^{220}$ but it will not alter the analysis of most racial classifications. In a racially heterogenous society, it is hard to imagine a social phenomenon that may be perfectly identified with race. ${ }^{221}$ If there is one, it certainly is not crime. Even the use of Hispanic appearance to increase suspicion of illegal alien status is substantially underinclusive and substantially overinclusive. ${ }^{222}$ Thus, whether the strict scrutiny test properly requires both a compelling state interest and a perfectly tailored classification or only the latter, the four disadvantaging classifications I have discussed fail that test. With the exception of the use of race as an identifying feature of a particular perpetrator, which does not involve a disadvantaging classification, reliance on race in detention decisions violates the guarantee of the equal protection of the laws. ${ }^{223}$

219. Note, Mental Illness: A Suspect Classification?, 83 YALE L.J. 1237, 1251 (1974); see Ely, The Wages of Crying Wolf: A Comment on Roe v. Wade, 82 Yale L.J. 920, 933-37 (1973).

220. Professor Gunther has argued that the Burger Court's reluctance to add to the number of suspect classifications stems from its desire to avoid assessment of how compelling an asserted interest is. See Gunther, supra note 200, at 21-22. Professor Ely advocates a permissible interest/perfect classification standard in conjunction with an argument that sex should be made a suspect classification. See Ely, supra note 219, at 933-37.

221. Racial classifications may be more accurate where physiological traits are involved. For example, three-tenths of one percent of the American black population suffers from sickle cell anemia, a serious hereditary disease. About nine percent of the black population carries the recessive gene while the incidence of the trait in the white population is negligible. Proposals to require only blacks to undergo sickle cell screening would therefore avoid either substantial over-or under-inclusiveness. See Note, Constitutional and Practical Considerations in Mandatory Sickle Cell Anemia Testing, 7 U.C.D. L. REv. 509 (1974); cf. Kaplan, Equal Justice in an Unequal World: Equality for the Negro-The Problem of Special Treatment, 61 Nw. U. L. REv. 363, 383 (1966) (regulation aimed at color rather than race might satisfy standard; e.g., state could require persons with dark skin to wear light-colored item of clothing when walking on road at night).

222. By INS figures, $10 \%$ to $15 \%$ of illegal aliens are not Hispanic, so using race to identify violators is substantially underinclusive. It is also grossly overinclusive, since even in border areas, only a small proportion of Hispanies are illegal aliens. See United States v. Brignoni-Ponce, 422 U.S. $873,886 \&$ n.12 (1975).

223. I am not arguing here that racial prejudice influencing an objectively justifiable decision should, if discovered, invalidate an arrest and require suppression of its fruits. Fourth Amendment case law is replete with examples of the principle that neither good faith nor sound reasoning is 


\section{Applications to Other Dubious Detention Criteria}

I have focused on racial factors in the detention decision because I find them most offensive. The various uses of race provide compelling examples of how casually both probabilistic and equal protection constraints are violated. They also counsel skepticism about the legitimacy of several other detention criteria.

\section{A. Probabilistic Constraints}

The first lesson from the analysis of race and detention concerns the predictive power of personal characteristics of the suspect. Courts should ignore police testimony that certain kinds of people are crime-prone absent evidence of such propensity. That the suspect looks like a "hippie"224 may be probative of criminal activity, but it may also be a vague and baseless stereotype. Similarly, that a suspect is incongruous with his surroundings should not be equated with increased likelihood of criminal activity. A well-dressed man in a shabby area, a stranger in a high-crime neighborhood, ${ }^{225}$ or a driver proceeding slowly in a rural area as if unfamiliar with the area, ${ }^{228}$ may be more likely to commit a crime than the typical resident, but he may merely be a victim of xenophobia. The police reflect societal prejudices, often magnified by the effects of self-fulfilling prophecies. ${ }^{227}$ Courts should ask for evidence supporting such generalizations; for judges to rely on assumed police "expertise" is irresponsible.

required of a police officer if objective justification for his actions is present. See, e.g., Washington v. Chrisman, 102 S. Ct. 812 (1982) (where officer could have entered room to prevent defendant's escape, search and seizure held valid); United States v. Payner, 447 U.S. 727, 735 (1980) (supervisory power of federal court does not extend to excluding evidence obtained by Government through delibcrate bad faith violations of one person's Fourth Amendment rights in order to secure evidence against another person); Scott v. United States, 436 U.S. 128, 136-38 (1978) (evaluation of compliance with wiretapping minimization requirement valid if "objectively reasonable," whether or not agents made any attempt to comply with requirement). This principle has frequently been attacked. See, e.g., Givelber, The Application of Equal Protection Principles to Selective Enforcement of the Criminal Law, 1973 U. ILL. L.F. 88; Tieger, Police Discretion and Discriminatory Enforcement, 1971 DukE L.J. 717; Note, The Right to Nondiscriminatory Enforcement of State Penal Laws, 61 ColUM. L. Rev. 1103 (1961); Note, Discriminatory Law Enforcement and Equal Protection From the Law, 59 YaLe L.J. 354 (1950). Nonetheless, it is well-established and poses different issues than does the reliance on race to justify an otherwise illegal detention.

224. See United States v. Sherman, 430 F.2d 1402, 1404-05 (9th Cir. 1970). The police officer may be referring to glazed eyes, needle marks, or other objective physical factors that indicate drug use. But he may also be referring to unconventional dress, which has no apparent probative value.

225. See State v. Smith, 347 So. 2d 1127, 1128-29 (La. 1977).

226. See United States v. Holland, 510 F.2d 453, 454 (9th Cir.) (police search of vehicle proceeding slowly in rural area reasonable), cert. denied, 422 U.S. 1010 (1975); cf. United States v. Nicholas, 448 F.2d 622, 625 (8th Cir. 1971) (out-of-state license plate by itself does not indicate criminal activity).

227. See supra note 172 . 


\section{B. Equal Protection Constraints}

The second lesson we should learn from the example of race is that detention decisions should be constrained by more than probabilistic concerns. ${ }^{228}$ Two other common factors in the decision to detain involve classifications that may call for close equal protection scrutiny.

\section{Gender}

Gender classifications require an intermediate standard of review. They must "serve important governmental objectives and must be substantially related to the achievement of those objectives."229 Gender is used as a factor in the decision to detain in at least three ways. The first use, as an identifying characteristic of a particular perpetrator, requires no special scrutiny because it is not a disadvantaging gender classification. ${ }^{230}$

The second use assumes a greater male propensity to commit crime; a man following a little old lady seems more dangerous than a woman doing the same thing. Detection of these propensity arguments requires some sensitivity, for they will rarely be as explicit as propensity arguments based upon race. ${ }^{231}$ Courts must therefore question whether they would find probable cause or reasonable suspicion if the defendant were of the opposite sex. If they would not, then heightened scrutiny is required. ${ }^{232}$

228. In addition to viewing race as a suspect classification, the Court has also declared classifications based on alienage to be suspect. See Graham v. Richardson, 403 U.S. 365, 371-72 (1971) (statutes denying welfare benefits to aliens violate equal protection clause; classifications based on alienage subject to strict scrutiny). The current status of alienage as a suspect classification is tempered by a generously construed exception for the "execution of broad public policy." See Ambach v. Norwick, 441 U.S. 68, 72-80 (1979) (upholding New York statute forbidding permanent teacher certification of aliens); Foley v. Connelie, 435 U.S. 291, 297-300 (1978) (statute limiting police force membership to U.S. citizens does not violate equal protection clause). This "public policy" exception seems irrelevant to detention cases.

Although alienage is considered in detentions for suspected violations of the immigration laws, this use does not require strict scrutiny because it clearly and directly falls within "the paramount federal power over immigration and naturalization." Cf. Hampton v. Mow Sun Wong, 426 U.S. 88, 99-101 (1976) (invalidating as not within paramount federal power civil service regulation barring resident aliens from employment).

I am aware of no case involving the use of alienage as a factor in establishing probable cause in circumstances unrelated to immigration. Were a police officer so to assert it as an aspect of probable cause or reasonable suspicion, the suppression hearing court should subject it to the same analysis proposed for race.

229. Craig v. Boren, 429 U.S. 190, 197 (1976) (striking down gender-based drinking age).

230. Cf. supra pp. 225-26, 239 (analyzing use of race as identifying feature). For the police to stop only men when looking for a rapist is not a gender classification even if the victim did not say that a male raped her; biological differences make masculinity an implicit part of the description.

231. Normal patterns of speech require the police, when speaking of the suspect, to recount what "he" or "she" was doing. The suppression hearing court may respond to prevailing stereotypes, yet not convey this reliance in its opinion since it too will "naturally" use male and female pronouns.

232. See Schnapper, Two Categories of Discriminatory Intent, 17 HARv. C.R.-C.L. L. REv. 31 (1982) (suggesting that test should be whether same decision would be made if disproportionate impact fell on non-disadvantaged group). 
The consequence of heightened scrutiny is not immediately obvious. An "important" government interest admittedly is at stake, but is the gender classification "substantially related" to the objective of crime detection? Perhaps this should depend upon the statistical fit between the gender classification and the specific crime suspected. For sexual assault, the correlation would be extremely high, ${ }^{233}$ but for nonviolent crimes, it would be much weaker. ${ }^{234}$

The third use of gender in detention decisions involves incongruity. A teen-age boy hanging around a park with little children is suspicious, ${ }^{235}$ as is a man carrying a woman's purse or overnight case. ${ }^{236}$ Certainly, these incongruities are rationally related to the likelihood that crime is afoot. But it is quite clear that these classifications do not impose equal burdens on both sexes; police do not suspect women of criminal activity when they express interest in typically male pursuits nor do they suspect criminal activity from a woman's wearing typically masculine apparel. In addition, use of gender incongruity as a detention factor might perpetuate traditional roles, just as the use of racial incongruity deters integration. Again, the results of heightened scrutiny are not indisputable. It might be necessary to distinguish subsets based upon the strength of the correlation between crime and the specific gender-incongruous conduct.

\section{Wealth}

The other common probable cause/reasonable suspicion factor that may intensify equal protection scrutiny is wealth. Police have asserted that they suspected the defendant because he was well dressed but in a "bad" neighborhood, ${ }^{232}$ was shabbily dressed in a wealthy neighborhood, ${ }^{238}$ or appeared to be poor (because of his location or residence or apparel) and was carrying an expensive item. ${ }^{239}$ All of these factors reflect a wealth classification. Dicta from the Warren Court implied that wealth classifica-

233. See United States v. Wickizer, 465 F.2d 1154, 1156 (8th Cir. 1972) (observation of two young girls in parked car with two men in area where several rapes occurred justified stop).

234. The correlation between prostitution and female gender, although obviously not absolute, is probably strong.

235. See Swett, supra note 172, at 85 (pointing oyt that such person might either be relative of child or molester).

236. See People v. Howard, 50 N.Y.2d 583, 589, 408 N.E.2d 908, 912, 430 N.Y.S.2d 578, 583 (carrying of woman's vanity case an equivocal fact), cert. denied, 449 U.S. 1023 (1980); People v. Davis, 36 N.Y.2d 280, 282, 326 N.E.2d 818, 819, 367 N.Y.S.2d 256, 257-58 (man's carrying woman's purse is not suspicious enough to justify arrest), cert. denied, 423 U.S. 876 (1975).

237. Sep United States v. McQueen, 458 F.2d 1049, 1050-51 (3d Cir. 1972) (well-dressed man in public housing).

238. See Racine v. State, 51 Ala. App. 484, 485-87, 286 So. 2d 890, 891-94 (1973) (persons with unkempt hair in old car with loud muffler in upper class neighborhood).

239. United States v. Robinson, 535 F.2d 881, 882-83 (5th Cir. 1976) (police stop of new car resembling police vehicle in poor black area). 
tions were suspect, ${ }^{240}$ but this position has been repudiated. ${ }^{241}$ Justice Marshall's compromise plea for heightened scrutiny ${ }^{242}$ has been ignored. ${ }^{243}$

The Burger Court's minimal scrutiny approach, however, evolved from consideration of de facto wealth classifications, ${ }^{244}$ rather than de jure classifications, such as those at issue in detention decisions. As pointed out by Professor Michelman at the end of the Warren Court's era, expanding suspect classification analysis to include de facto wealth classifications would have conflicted with deeply entrenched "free market" values. ${ }^{245}$ The difficulties inherent in condemning the market process do not, however, constrain review of de jure wealth discrimination. ${ }^{246}$ The disparaging term "invidious" seems appropriate for de jure wealth classifications,

240. See, e.g., McDonald v. Board of Election Comm'rs, 394 U.S. 802, 807 (1969) ("careful examination . . . especially warranted where lines are drawn on the basis of wealth or race . . two factors which would independently render a classification highly suspect and thereby demand a more exacting judicial scrutiny"); Harper v. Virginia Bd. of Elections, 383 U.S. 663, 668 (1966) ("Lines drawn on the basis of wealth or property, like those of race, . . . are traditionally disfavored.").

241. See James v. Valtierra, 402 U.S. 137, 142 (1971) (implying that wealth classifications, unlike racial classifications, are not suspect).

242. See San Antonio Indep. School Dist. v. Rodriguez, 411 U.S. 1, 121-22 (1973) (Marshall, J., dissenting):

That wealth classifications alone have not necessarily been considered to bear the same high degree of suspectness as have classifications based on, for instance, race or alienage may be explainable on a number of grounds. The "poor" may not be seen as politically powerless as certain discrete and insular minority groups. Personal poverty may entail much the same social stigma as historically attached to certain racial or ethnic groups. But personal poverty is not a permanent disability; its shackles may be escaped. Perhaps most importantly, though, personal wealth may not necessarily share the general irrelevance as a basis for legislative action that race or nationality is recognized to have. While the "poor" have frequently been a legally disadvantaged group, it cannot be ignored that social legislation must frequently take cognizance of the economic status of our citizens. Thus, we have generally gauged the invidiousness of wealth classifications with an awareness of the importance of the interests being affected and the relevance of personal wealth to those interests.

243. 411 U.S. at 18-28.

244. See generally' id. (upholding local property tax financing of education where substantial interdistrict disparities in per-pupil expenditures resulted from differences in taxable property values among the districts); James v. Valtierra, 402 U.S. 137 (1971) (upholding Galifornia's constitutional requirement that low-rent housing projects have prior approval by local referenda). In Valtierra, the majority saw no discrimination against the poor since low-income public housing was not the only government expenditure subject to referenda, id. at 142; the dissent asserted that this was facial discrimination on the basis of poverty, id. at 144 (Marshall, J., dissenting).

245. See Michelman, The Supreme Court, 1968 Term-Foreword: On Protecting the Poor through the Fourteenth Amendment, 83 HaRv. L. REv. 7, 27-28 (1969):

[U]nlike a de facto racial classification which usually must seek its justifications in purposes completely distinct from its race-related impacts, a de facto pecuniary classification typically carries a highly persuasive justification inseparable from the very effect which excites antipathy-i.e., the hard choices it forces upon the financially straitened. For the typical form assumed by such a classification is simply the charging of a price, reasonably approximating cost, for some good or service which the complaining person may freely choose to purchase or not to purchase. ... We usually regard it as both the fairest and most efficient arrangement to require each consumer to pay the full market price of what he consumes, limiting his consumption to what his income permits.

246. Sep id. at 28-29 (de jure wealth discrimination should require adequate justification). 
because with no market justification, they resemble racial classifications in their suggestion of oppression and stigma. Moreover, heightened scrutiny for explicit wealth discrimination in detention decisions is not foreclosed. Earlier cases struck down de jure wealth classifications, albeit on other grounds, ${ }^{247}$ and no recent case has presented the issue. Defense attorneys-and courts-should therefore consider an objection of invidious discrimination in those detentions where economic class propensity or incongruity is alleged to have increased suspicion.

I have only sketched concern about two additional semi-suspect factors. It may be that close analysis of these "dubious" factors will validate one or both, or validate them in some contexts. My point is that empirical relationship to criminal activity is only the first inquiry. The second inquiry must balance the revealed law enforcement interests against other constitutionally enshrined values.

\section{Policy Constraints}

Finally, I think that the sharp dichotomy between competent trial evidence and competent suppression hearing evidence is misguided. The possibility of prejudice is omnipresent in a jury trial, but prejudice may sneak in the back door at a suppression hearing. When the feared prejudice is overt, courts may be more trustworthy than juries. We may shield the jury from knowledge of the defendant's prior record, ${ }^{248}$ yet not hesitate to give the suppression court that information. The record has probative value, which the judge can separate from its prejudicial tendency. With other factors, prejudice may be hidden in the police officer's "expertise." For example, when a police officer describes a neighborhood as "high crime" or "drug-prone," a court cannot exercise the judicial detachment relied upon with factors involving overt prejudice. The court may completely accept the expertise, risking that the officer's prejudice about ghetto neighborhoods clouds his evaluation of the probability of crime contributed by the neighborhood. The court may also reject the testimony.

These two alternatives are both too extreme. Caution is most appropriate. Courts should be reluctant to place substantial weight on facts where expertise and prejudice often intersect. This is the approach that the California courts have taken to testimony about a "high-crime" area. Because

247. See Cipriano v. City of Houma, 395 U.S. 701, 706 (1969) (per curiam) (striking down property ownership restriction on right to vote because fundamental interest is infringed); Edwards v. California, 314 U.S. 160, 177 (1941) (invalidating California law barring persons from bringing indigents into state because such law impermissibly burdens interstate commerce).

248. Sep FED. R. Evid. 404(b) ("Evidence of other crimes, wrongs, or acts is not admissible to prove the character of a person in order to show that he acted in conformity therewith."); see also id. 609 (a) (limiting impeachment by evidence of conviction to cases in which probative value of evidence outweighs its prejudicial effect). 
the factor is "easily subject to abuse" and because it is a factor outside the individual's control, the factor is appraised with great circumspection. ${ }^{249}$

Not all factors based on expertise warrant such caution. The risks of error or unfairness are small when courts credit police expertise concerning the usual behavioral patterns of numbers runners or the packaging used by diamond smugglers. It is the intersection of expertise with common prejudices that produces a greater likelihood of error. This intersection also creates injustice, or at least the appearance of injustice. The suspect's social or economic class, whether or not it constitutionally compels heightened scrutiny, is the factor most like "high-crime" neighborhoods in the feeling of unfairness its use produces. Furthermore, both the factors of class and neighborhood may easily be used as facades for race; this possibility should induce additional reluctance about attaching substantial weight to their presence. ${ }^{280}$

\section{ConCLusion}

I end this Article with the man who began my interest in the subject. My client, José Tirado, ${ }^{251}$ was stopped for pushing a two-wheeled shopping cart with a TV and speakers in it. Not a month before I was assigned the case, I pushed just such a shopping cart loaded with similar items past several police officers. A friend of mine had also moved a TV in that manner in the same month. Mr. Tirado is Hispanic and was poorly dressed; I am blond and was dressed for court. Mr. Tirado was walking in a poor New York City neighborhood; I was walking in Brooklyn Heights. Mr. Tirado increased his pace when followed by four plainclothes officers of another race; I certainly would have done the same.

249. See People v. Bower, 24 Cal. 3d 638, 645, 597 P.2d 115, 119, 156 Cal. Rptr. 856, 860 (1979); In re Tony C., 21 Cal. 3d 888, 897, 582 P.2d 957, 962, 148 Cal. Rptr. 366, 371 (1978).

250. Another likely surrogate for race is language. Courts should therefore be cautious in affording great weight to the speaking of Spanish (or Chinese). For a consideration of the problem of variables that function as surrogates for race in the prediction of parole success, see Coffee, The Repressed Issues of Sentencing: Accountability, Predictability, and Equality in the Era of the Sentencing Commission, 66 GEo. L.J. 975, 1002 n.71 (1978).

While less troubling, youth, a "hippie" appearance, Rastafarian affiliation, and other unpopular or unsavory voluntary associations are also likely to generate some "expert" prejudice and consequently exaggeration of their probative value. Perhaps these factors too should be more carefully examined. These policy considerations, as invoked by the California courts in the "high-crime" neighborhood cases, would not flatly prohibit consideration of the disfavored factors, but would invite a skeptical outlook toward the weight they should be accorded.

Other policy considerations than those I have suggested are possible. Professor Underwood has proposed a two-tier hierarchy of predictors. In her view, factors beyond the individual's control are the least desirable predictors because they present the greatest threat to individual autonomy. Underwood, supra note 210 , at 1436 . In addition, predictors that induce, reward, or punish behavior which "falls in a zone in which there is a strong social commitment to protecting an individual's private and personal choices" should also be avoided when reasonably reliable substitutes are available. Id. at 1437-38.

251. See People v. Tirado, 79 A.D.2d 907, 434 N.Y.S.2d 398 (1981). 
When Mr. Tirado attempted to engage a large black woman in conversation (the officer stressed her race and size), he was stopped; neither I nor my friend was detained or even followed. The suppression court sustained the police action. At oral argument of the appeal, one judge commented that he personally had moved furniture with such a shopping cart. Nevertheless, the court unanimously upheld the seizure.

One could always respond that the police should have stopped and questioned all four of us. I will not dispute that here; how much suspicion is "enough" is a question for another day. One could instead argue that regardless of what courts do, police will still respond to race, poverty, and bad neighborhoods - and that the only consequence of adopting my analysis is increased suppression of reliable evidence and release of the guilty. To my mind, this position turns its back on all the harassed minority group members the courts never see, those innocent citizens who are detained by reason of their race, but exonerated before formal charges are filed.

Certainly, judicial refusal to consider race as an acceptable component of probable cause will not eliminate police beliefs that poor Hispanics in bad neighborhoods are likely to be committing crimes. Whether judicial pronouncements that race is irrelevant to suspicion will deter police officers from detaining persons on the basis of their race is more difficult. This is a tiny part of the larger argument about the exclusionary rule: Does the sanction of exclusion effectively inhibit police illegality or does it merely set free some factually guilty defendants?252

I am of the more optimistic view that the police can be encouraged to respect constitutional rights, but $I$ do not think that the argument that courts should disregard race rests upon an empirical assumption that police will follow suit. At the very least, declaring that it is illegitimate to consider these factors in decisions to detain will affect civil suits, both those seeking injunctive relief and those seeking damages for an unlawful arrest.

That constitutional dictates have not been and might not be enforced is not sufficient reason for courts to stop espousing them. It is important for the courts to say that suspicion based on factors beyond a person's control is wrong, and that action clearly based upon such suspicion will not be tolerated. Such a statement may be small consolation to the minority

252. There is substantial literature on the value of the exclusionary rule as a deterrent. See, e.g., Canon, The Exclusionary Rule: Have Critics Proven That It Doesn't Deter Police?, 62 Judicature 398 (1979); Schlesinger, The Exclusionary Rule: Have Proponents Proven That It Is a Deterrent to Police?, 62 Judicature 404 (1979). For a survey of earlier literature on the question, see Comment, Trends in Legal Cominenlary on the Exclusionary Rule, 65 J. CRIM. L. \& CRIminology 373 (1974). 
group member stopped on the basis of his race, but it is better than nothing. ${ }^{283}$ To bow to executive refusal to enforce the law

... would be enshrining the rather perverse notion that traditional rights are not to be protected in precisely those instances when protection is essential, i.e., when a dominant group has succeeded in temporarily frustrating exercise of those rights. We prefer a view more compatible with the theory of this nation's founding: rights do not cease to exist because a government fails to secure them. See The Declaration of Independence (1776). ${ }^{254}$

253. Public perception of the courts as protectors of minorities may be deteriorating. In $1968,72 \%$ of blacks compared to $30 \%$ of whites viewed the Supreme Court favorably, but a 1974 study found that black approval had fallen to match the lower approval rate of whites. See Siegelman, Black-While Differences in Attitudes Toward the Supreme Court: A Replication in the 1970's, 60 Soc. Scr. Q. 113 (1979).

254. Mescalero Apache Tribe v. New Mexico, 630 F.2d 724, 730 (10th Cir. 1980) (rejecting state's argument that Mescaleros could not have exclusive land rights since "tide of white settlers obliterated any traditional territory"). 